University of Chicago Law School

Chicago Unbound

Journal Articles

Faculty Scholarship

2018

\title{
Why Limits on Contributions to Super PACs Should Survive Citizens United
}

\author{
Albert W. Alschuler \\ Laurence $\mathrm{H}$. Tribe \\ Norman Eisen \\ Richard W. Painter
}

Follow this and additional works at: https://chicagounbound.uchicago.edu/journal_articles

Part of the Law Commons

\section{Recommended Citation}

Albert Alschuler, Laurence H. Tribe, Norman Eisen \& Richard Painter, "Why Limits on Contributions to Super PACs Should Survive Citizens United," 86 Fordham Law Review 2299 (2018).

This Article is brought to you for free and open access by the Faculty Scholarship at Chicago Unbound. It has been accepted for inclusion in Journal Articles by an authorized administrator of Chicago Unbound. For more information, please contact unbound@law.uchicago.edu. 


\title{
ARTICLES \\ WHY LIMITS ON CONTRIBUTIONS TO SUPER PACS SHOULD SURVIVE CITIZENS UNITED
}

\author{
Albert W. Alschuler, ${ }^{*}$ Laurence H. Tribe, ${ }^{* *}$ \\ Norman L. Eisen ${ }^{* * *} \&$ Richard W. Painter****
}

Soon after the Supreme Court decided Citizens United v. FEC, the D.C. Circuit held all limits on contributions to super PACs unconstitutional. Its decision in SpeechNow.org v. FEC created a regime in which contributions to candidates are limited but in which contributions to less responsible groups urging votes for these candidates are unbounded.

No legislator voted for this system of campaign financing, and the judgment that the Constitution requires it is astonishing. Forty-two years ago, Buckley v. Valeo held that Congress could limit contributions to candidates because these contributions are corrupting or create an appearance of corruption. According to the D.C. Circuit, however, Congress may not prohibit multi-million-dollar contributions to satellite campaigns because these contributions do not create even an appearance of corruption.

The D.C. Circuit said that a single sentence of the Citizens United opinion compelled its result. It wrote, "In light of the Court's holding as a matter of law that independent expenditures do not corrupt or create the appearance of corruption, contributions to groups that make only independent expenditures also cannot corrupt or create the appearance of corruption."

This Article contends that, contrary to the D.C. Circuit's reasoning, contributions to super PACs can corrupt even when expenditures by these groups do not. Moreover, the statement that the D.C. Circuit took as its premise was dictum, and the Supreme Court did not mean this statement to be taken in the way the D.C. Circuit took it.

The Supreme Court's long-standing distinction between contribution limits and expenditure limits does not rest on the untenable proposition that

* Julius Kreeger Professor Emeritus, the University of Chicago Law School.

** Carl M. Loeb University Professor and Professor of Constitutional Law, Harvard Law School.

*** Senior Fellow, Brookings Institution; former Ambassador to the Czech Republic and former Special Assistant and Special Counsel to the President for Ethics and Government Reform (Obama administration).

**** Walter Richey Professor, University of Minnesota Law School; former Associate Counsel to the President (George W. Bush administration). The authors are grateful to Ronald A. Fein for exceptionally helpful and perceptive comments. 
candidates cannot be corrupted by funds paid to and spent on their behalf by others. Rather, Buckley noted five differences between contributions and expenditures. A review of these differences makes clear that contributions to super PACs cannot be distinguished from the contributions to candidates whose limitation the Court upheld.

The ultimate question posed by Buckley is whether super PAC contributions create a sufficient appearance of corruption to justify their limitation. This Article reviews the statements of candidates of both parties in the 2016 presidential election, the views of Washington insiders, and public opinion polls. It shows that SpeechNow has sharpened class divisions and helped to tear America apart.

The Justice Department did not seek Supreme Court review of the SpeechNow decision. In a statement that belongs on a historic list of wrong predictions, Attorney General Holder explained that the decision would "affect only a small subset of federally regulated contributions." Although eight years have passed since SpeechNow, the Supreme Court has not decided whether the Constitution guarantees the right to give unlimited funds to super PACs. A final section of this Article describes the efforts of members of Congress and candidates for Congress to bring that question before the Court. The Federal Election Commission is opposing their efforts, offering arguments that, if accepted, would be likely to keep the Court from ever deciding the issue.

INTRODUCTION

A. The Indefensible Policy and Incomprehensible Law Created by SpeechNow.org v. FEC..................................................... 2301

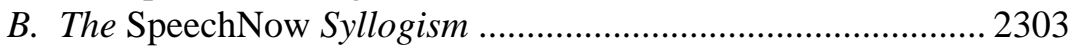

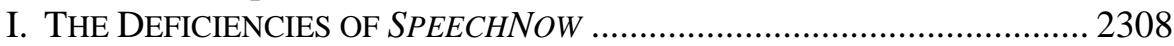

A. SpeechNow's Supposed Syllogism Is Fallacious .................... 2308

B. The Statement upon Which the D.C. Circuit Relied Was

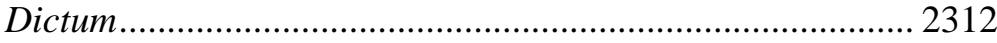

C. The Supreme Court Did Not Mean Its Dictum Literally......... 2314

II. THE DIFFERENCES BETWEEN CONTRIBUTIONS AND EXPENDITURES 2317

A. Supreme Court Precedents ................................................. 2317

B. Are Contributions to Super PACs Really Contributions?....... 2320

C. The Supreme Court's Reasons for Treating Contributions as Low-Value Speech.

D. The Supreme Court's Reasons for Treating Contributions as More Corrupting than Expenditures..................................... 2322

E. Why Contributions and Expenditures Are Not Fungible: The False Allure of the Hydraulic Hypothesis ............................... 2325

III. THE APPEARANCE OF CORRUPTION .............................................. 2327

A. Wealth Disparity, Mistrust, and Corruption ........................... 2327

B. Defining Corruption and the Appearance of Corruption ....... 2333

C. The Presidential Campaign of 2016 …................................... 2338 
D. Some Views of Elected Officials, Lobbyists, and Donors....... 2340

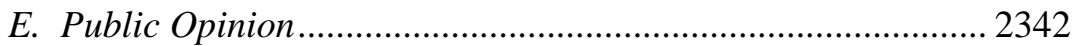

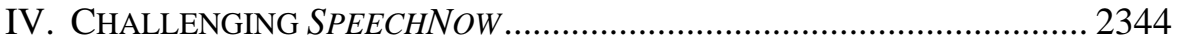

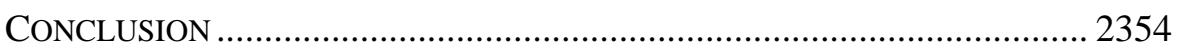

\section{INTRODUCTION}

\section{A. The Indefensible Policy and Incomprehensible Law Created by SpeechNow.org v. FEC}

In 2010, two months after the U.S. Supreme Court decided Citizens United v. FEC, 1 the D.C. Circuit held all limits on contributions to super PACs unconstitutional. Its decision in SpeechNow.org v. FEC ${ }^{2}$ created a regime in which contributions to candidates are limited but in which contributions to "independent expenditure committees" urging votes for these candidates are unbounded.

In the 2016 presidential campaign, for example, federal law barred hedge fund manager Donald Sussman from contributing as much as \$5500 to Hillary Clinton's campaign. 3 Similarly, it barred hedge fund manager Robert Mercer from contributing \$5500 to Donald Trump's campaign. Forty years earlier, in Buckley v. Valeo, ${ }^{4}$ the Supreme Court had upheld limits on contributions to candidates. 5

But federal law did not prohibit Donald Sussman from contributing \$21 million to Priorities USA Action, a super PAC whose principal mission was to place advertisements on behalf of Clinton. ${ }^{6}$ And it did not bar Robert Mercer from contributing \$15.5 million to Make America Number 1, a super PAC that supported Ted Cruz in the Republican primaries and Trump in the general election.7 Until 2010, a federal statute limited contributions to groups

1. 558 U.S. 310 (2010).

2. 599 F.3d 686 (D.C. Cir. 2010) (en banc).

3. The law capped contributions to campaigns for federal office at $\$ 2700$ per election or $\$ 5400$ for both the primary and general elections. Contribution Limits for 2015-2016, FED. ELECTION COMM'N, https://www.fec.gov/updates/contribution-limits-for-2015-2016/ [https://perma.cc/9XJ6-9JBG] (last visited Mar. 15, 2018).

4. 424 U.S. 1 (1976) (per curiam).

5. Id. at 58 .

6. See Outside Spending: Sussman, S. Donald: Donor Detail, OpenSecrets.org, http://www.opensecrets.org/outsidespending/donor_detail.php?cycle=2016\&id=U00000046 04\&type $=$ I\&super=N\&name=Sussman+S.+Donald $\quad$ [https://perma.cc/6WXN-4G9J] (last visited Mar. 15, 2018); see also Priorities Action USA, OPENSECRETS.ORG, https://www.opensecrets.org/outsidespending/detail.php?cmte=C00495861\&cycle=2016 [https://perma.cc/EEF5-Q3JF] (last visited Mar. 15, 2018).

7. See Outside Spending: Mercer, Robert L.: Donor Detail, OpenSECRETS.ORG, http://www.opensecrets.org/outsidespending/donor_detail.php?cycle=2016\&id=U00000036 82\&type=I\&super=S\&name=Mercer+Robert+L [https://perma.cc/F3XF-GC3L] (last visited Mar. 15, 2018); see also Make America Number 1, OpENSECRETS.ORG, https://www.opensecrets.org/outsidespending/recips.php?cmte=C00575373\& cycle=2016 [https://perma.cc/XD3G-TZXC] (last visited Mar. 15, 2018). 
like Priorities USA Action and Make America Number 1 to $\$ 5000$ per year, 8 but SpeechNow held this statute unconstitutional.

"Super PACs" or "independent expenditure committees" are groups that do not make contributions to candidates but instead place their own advertisements supporting candidates or disparaging their opponents. Although these groups may not coordinate their expenditures with those of an official campaign, ${ }^{9}$ their managers often understand that their job is to attack an opponent while the candidate they support takes a higher road.10 Super PACs have been called "the attack dogs and provocateurs of modern politics."11 The advertisements they produce contribute to the nation's cynicism about politics, a cynicism that runs especially deep among young people.12 The candidates they support need not take responsibility for what they say, and the groups usually disappear once an election is over.

Limits on contributions to candidates no longer restrict how much people can give to electoral efforts. They simply require contributors to channel their funds to less responsible and more destructive speakers. 13 No sane

8. 52 U.S.C. § 30116(a)(1)(C) (2012).

9. See 11 C.F.R. §§ 109.20-.23 (2018). “Independent expenditure committees” need not be entirely independent. Candidates may, within limits, urge people to contribute to these groups and may speak at their gatherings. See FEC, Advisory Opinion 2011-12 (Majority PAC and House Majority PAC) (June 30, 2011), http://saos.fec.gov/saos/searchao? AONUMBER=2011-12 [https://perma.cc/8PCD-M8K3] (enter "2011-12” in "Go to AO number" field and press "Search"). They may thank contributors for making donations to super PACs, share fundraising consultants with super PACs, and provide lists of prospective donors to super PACs. Note, Working Together for an Independent Expenditure, 128 HARV. L. REV. 1478, 1480, 1485-86 (2015). A recent solicitation for funds by a super PAC advised a prospective donor, "We are the blessed Super PAC by Sen. Toomey ... . I am his former senior aide and finance director, and I am working with his former chief-of-staff.” Robert Faturechi \& Lauren Kirchner, Super PAC to Billionaire: We Need More Money to Save a Republican Senate, ProPublica (Oct. 14, 2016, 12:55 PM), https://www.propublica.org/ article/super-pac-to-billionaire-we-need-more-money-to-save-a-republican-senate [https://perma.cc/Q7SJ-U4M5].

10. See David A. Graham, The Incredible Negative Spending of Super PACs-in 1 Chart, AtLANTIC (Oct. 15, 2012), https://www.theatlantic.com/politics/archive/2012/10/theincredible-negative-spending-of-super-pacs-in-1-chart/263643/ [https://perma.cc/3L77REW6] (reporting that, in the 2012 presidential campaign, Republican super PACs spent three times more attacking the Democratic candidate than they did supporting the Republican candidate and that Democratic super PACs spent nine times more attacking the Republican candidate than they did supporting the Democratic candidate).

11. Jeremy W. Peters, Conservative 'Super PACs' Synchronize Their Messages, N.Y. TiMEs (Sept. 24, 2012), http://www.nytimes.com/2012/09/25/us/politics/conservative-superpacs-sharpen-their-synchronized-message.html [https://perma.cc/4YBW-RVZQ].

12. See Pew Research Ctr., Beyond Distrust: How Americans View Their GOVERNMENT 4 (2015), http://assets.pewresearch.org/wp-content/uploads/sites/5/2015/11/1123-2015-Governance-release.pdf [https://perma.cc/U2YP-99AZ]; Sheryl Gay Stoleberg, For 'Millennials,' a Tide of Cynicism and a Partisan Gap, N.Y. Times (Apr. 29, 2013), http://www.nytimes.com/2013/04/30/us/politics/for-millennial-voters-a-tide-of-cynicismtoward-politics.html [https://perma.cc/SQ3M-5QAQ].

13. See Michael W. McConnell, Reconsidering Citizens United as a Press Clause Case, 123 YALE L.J. 412, 455 (2013) ("I am skeptical of any governmental effort to police campaign speech to make it less negative, vitriolic, or immoderate, but there is little to be said for laws that exacerbate these vices.”). Donors typically give the maximum allowable amount to the candidates they favor and then make additional donations to super PACs supporting the same candidates. In doing so, they apparently seek to obtain with super PAC contributions what the 
legislator would vote in favor of this system of campaign financing, and none ever has. The United States has this regime because the D.C. Circuit held that the First Amendment requires it.

The claim that the Constitution requires this topsy-turvy state of affairs, however, is astonishing. According to the Supreme Court, Congress may prohibit a $\$ 5500$ contribution to an official campaign because this contribution is corrupting or creates the appearance of corruption.14 According to the D.C. Circuit, however, Congress may not prohibit a \$20 million contribution to a super PAC because this contribution does not create even an appearance of corruption. 15 The D.C. Circuit reached this conclusion not on the basis of empirical investigation but as a matter of law. ${ }^{16}$

\section{B. The SpeechNow Syllogism}

The D.C. Circuit did not argue that the system of campaign financing it created was desirable or defensible, and it did not argue that the law it created was sound or coherent. The court made no effort to distinguish contributions to super PACs from contributions to candidates. It offered no defense of the merits of its ruling. The court simply announced that a single sentence of the Citizens United opinion compelled its result.

The Supreme Court wrote in Citizens United, "We now conclude that independent expenditures ... do not give rise to corruption or the appearance of corruption,"17 and the D.C. Circuit declared,

In light of the Court's holding as a matter of law that independent expenditures do not corrupt or create the appearance of quid pro quo corruption, contributions to groups that make only independent expenditures also cannot corrupt or create the appearance of corruption. 18

This Article will refer to this declaration as the SpeechNow syllogism: If the money going out of a super PAC does not corrupt, the money coming into a super PAC cannot corrupt either.

Citizens United and SpeechNow presented very different issues. In Citizens United, the Supreme Court struck down limits on a political group's expenditures while the issue in SpeechNow was the validity of limiting contributions to a political group. The Court has treated these two sorts of restrictions differently. In Buckleyv. Valeo, although the Court upheld limits

law prevents them from getting with direct donations to candidates. See STEPHEN R. Weissman, The SpeEchNow Case and the Real World of Campaign Finance tbls.1-2 (2016), https://freespeechforpeople.org/wp-content/uploads/2016/10/FSFP-WeissmanReport-final-10-24-16.pdf [https://perma.cc/7LQL-XF65].

14. Buckley said, "It is unnecessary to look beyond the Act's primary purpose to limit the actuality and appearance of corruption resulting from large individual financial contributions in order to find a constitutionally sufficient justification for the $\$ 1000$ contribution limitation.” Buckley v. Valeo, 424 U.S. 1, 26 (1976) (per curiam).

15. SpeechNow said, "[C]ontributions to groups that make only independent expenditures ... cannot corrupt or create the appearance of corruption.” SpeechNow.org v. FEC, 599 F.3d 686, 694 (D.C. Cir. 2010) (en banc).

16. Id.

17. Citizens United v. FEC, 558 U.S. 310, 357 (2010).

18. SpeechNow, 599 F.3d at 694. 
on contributions to candidates, 19 it struck down limits on expenditures by candidates.20 It also struck down limits on expenditures by individuals and groups that independently advocate a candidate's election. ${ }^{21}$

Decisions since Buckley have confirmed that expenditure limits and contribution limits are judged by different standards. Limits on expenditures are subject to strict scrutiny; these limits must "further a compelling interest" and must be "narrowly tailored to achieve that interest."22 Contribution limits are not subject to strict scrutiny. These limits must merely be "closely drawn" to match a "sufficiently important interest." 23 In the years since Buckley, the Supreme Court has struck down every expenditure limit to come before it, but it has upheld most contribution limits. ${ }^{24}$ A later section of this Article will discuss the reasons for the Court's distinction.25

Citizens United did not disrupt the pattern of the earlier cases. The Supreme Court observed that "contribution limits, . . . unlike limits on independent expenditures, have been an accepted means to prevent quid pro quo corruption.”26 In its opening paragraph, its closing paragraph, and many places in between, the Court emphasized that the case before it concerned only expenditure limits.

In SpeechNow, the court acknowledged for purposes of decision that the case before it concerned only contribution limits and that these limits were not subject to strict scrutiny. The court nevertheless saw Citizens United as implicitly resolving the issue the Court had set aside-the validity of

19. Buckley, 424 U.S. at 23-35.

20. Id. at $54-58$.

21. Id. at 39-51.

22. See, e.g., Citizens United, 558 U.S. at 340 (quoting FEC v. Wis. Right to Life, 551 U.S. 449, 464 (2007)).

23. See, e.g., FEC v. Beaumont, 539 U.S. 146, 158-59 (2003); Nixon v. Shrink Mo. Gov't PAC, 528 U.S. 377, 378-88 (2000).

24. The Court struck down expenditure limits in Buckley; First National Bank of Boston v. Bellotti, 435 U.S. 765 (1978); FEC v. National Conservative Political Action Committee, 470 U.S. 480 (1985); FEC v. Massachusetts Citizens for Life, 479 U.S. 238 (1986); Colorado Republican Federal Campaign Committee v. FEC (Colorado I), 518 U.S. 604 (1996); and Citizens United.

The Court upheld contribution limits in Buckley; California Medical Ass'n v. FEC, 453 U.S. 182 (1981); Shrink Missouri Government PAC; Beaumont; and McConnell v. FEC, 540 U.S. 93 (2003), overruled in part by Citizens United, 558 U.S. 310. It struck down contribution limits in Citizens Against Rent Control v. Berkeley, 454 U.S. 290 (1981) (declaring limits on contributions to groups supporting or opposing referendums unconstitutional because these contributions pose no risk of corrupting public officials); Randall v. Sorrell, 548 U.S. 230 (2006) (invalidating Vermont's extremely low limits); and McCutcheon v. FEC, 134 S. Ct. 1434 (2014) (invalidating limits on the total amount an individual may contribute to all candidates and political committees during a single election cycle). In FEC v. Colorado Republican Federal Campaign Committee (Colorado II), 533 U.S. 431 (2001), the Court said, "[W]e have routinely struck down limitations on independent expenditures by candidates, other individuals, and groups, while repeatedly upholding contribution limits," id. at 441-42.

25. See infra Part II.

26. Citizens United, 558 U.S. at 359. 
contribution limits.27 The SpeechNow syllogism rendered the distinction between contributions and expenditures irrelevant:

[B]ecause Citizens United holds that independent expenditures do not corrupt or give the appearance of corruption as a matter of law, then the government can have no anti-corruption interest in limiting contributions to independent expenditure-only organizations. No matter which standard of review governs contribution limits, the limits on contributions to SpeechNow cannot stand. 28

In Citizens United, according to the D.C. Circuit, "the [Supreme] Court held that the government has no anti-corruption interest in limiting independent expenditures." 29 It italicized the word no. Whatever the standard of review might be, the court said, "something . . . outweighs nothing every time." 30 Acknowledging even a smidgen, soupçon, or scintilla of regulatory interest would have undercut the court's analysis entirely. Under the Supreme Court's two-tier standard of review, an interest that cannot justify a restriction of expenditures can justify a restriction of contributions, but the government may not restrict even low-value speech when its interest in doing so is nonexistent.

SpeechNow was a unanimous en banc decision. The court's syllogism persuaded all nine of its judges, including the three appointed by Democrats. In the years since SpeechNow, its syllogism has convinced five additional federal courts of appeals to strike down limits on contributions to super PACs. ${ }^{31}$ The Federal Election Commission (FEC) has acquiesced in the SpeechNow decision, 32 and academic criticism of the ruling has been

27. See id. at 359 ("Citizens United . . . has not suggested that the Court should reconsider whether contribution limits should be subjected to rigorous First Amendment scrutiny.”).

28. SpeechNow.org v. FEC, 599 F.3d 686, 696 (D.C. Cir. 2010) (en banc).

29. Id. at 693.

30. Id. at 695 (alteration in original) (quoting Nat'l Ass'n of Retired Fed. Emps. v. Horner, 879 F.2d 873, 879 (D.C. Cir. 1989)).

31. Some of these decisions approved only preliminary injunctions. They thus resolved the question tentatively but not definitively. See N.Y. Progress \& Prot. PAC v. Walsh, 733 F.3d 483, 487, 489 (2d Cir. 2013) (approving a preliminary injunction); see also Vt. Right to Life Comm. v. Sorrell, 758 F.3d 118, 140 (2d Cir. 2014) (leaving open whether the Second Circuit should follow SpeechNow despite that circuit's approval of a preliminary injunction against the enforcement of Super Pac contributions limits in New York Progress \& Protection PAC); Republican Party of N.M. v. King, 741 F.3d 1089, 1095-96, 1103 (10th Cir. 2013) (approving a preliminary injunction); Texans for Free Enter. v. Tex. Ethics Comm'n, 732 F.3d 535, 537-38 (5th Cir. 2013) (same); Wis. Right to Life State Political Action Comm. v. Barland, 664 F.3d 139, 154-55 (7th Cir. 2011); Long Beach Area Chamber of Commerce v. City of Long Beach, 603 F.3d 684, 696-99 (9th Cir. 2010). In all of the cases striking down limitations on contributions to super PACS, government lawyers argued that contribution limits differed from expenditure limits, and, in all of them, courts responded by endorsing the SpeechNow syllogism. The Seventh Circuit described this syllogism as inexorable. See Barland, 664 F.3d at 154 . One other court of appeals had made a ruling resembling SpeechNow prior to the D.C. Circuit's decision. See N.C. Right to Life, Inc. v. Leake, 525 F.3d 274, 308 (4th Cir. 2008) (holding that North Carolina did not make a sufficient evidentiary showing to justify its limit on contributions to super PACs); see also EMILY's List v. FEC, 581 F.3d 1, 11, 25 (D.C. Cir. 2009) (foreshadowing the D.C. Circuit's decision in SpeechNow).

32. See FEC, Advisory Opinion 2010-11 (Commonsense Ten) (July 22, 2010), http://saos.fec.gov/saos/searchao?AONUMBER=2010-11 [https://perma.cc/QT2T-X9WU] (enter “2010-11” in “Go to AO number” field and press "Search”). 
sparse.33 One commentator declared that Citizens United "utterly removed room for argument about Super PACs" 34 and "made SpeechNow an easy case with only one possible outcome."35

The Justice Department did not seek Supreme Court review of the SpeechNow decision. Attorney General Eric Holder explained in a letter to Senator Harry Reid, “[T]he court of appeals' decision will affect only a small subset of federally regulated contributions . . ..”36

Holder's statement belongs on a historic list of wrong predictions near that of the manager of the Grand Ole Opry who told Elvis Presley, "You ain't goin' nowhere, son-you ought to go back to drivin' a truck.”37 In 2016, 2392 super PACs campaigning in federal elections raised \$1.79 billion.38 Sixty-one percent of this amount came from one hundred donors (individuals and groups),39 and 43 percent came from the top one hundred individual donors. 40 The amounts given by these top donors ranged from $\$ 89.5$ million (Thomas Steyer) to $\$ 1.36$ million (Steven Spielberg). 41 The average amount

33. One of the authors of this Article did criticize SpeechNow. See generally Albert W. Alschuler, Limiting Political Contributions After McCutcheon, Citizens United, and SpeechNow, 67 FLA. L. REV. 389 (2016). Alschuler's criticism appeared, however, amidst a 120-page article addressing other topics. With his permission and that of the Florida Law Review, this coauthored Article sometimes draws from and builds upon Alschuler's earlier article without using quotation marks or noting the pages of the earlier article in which his analysis appeared. See also Stephen R. Weissman, Courting Corruption, AM. INTEREST (Aug. 25, 2017), https://www.the-american-interest.com/2017/08/25/courting-corruption/ [https://perma.cc/Z369-F92N] (last visited Mar. 15, 2018) (criticizing SpeechNow).

34. Michael S. Kang, Essay, The Year of the Super PAC, 81 GEO. WASH. L. REV. 1902, 1912 (2013).

35. Id. at 1911.

36. Letter from Eric H. Holder, Jr., U.S. Attorney Gen., to Harry Reid, U.S. Senate Majority Leader (June 16, 2010), https://www.justice.gov/sites/default/files/oip/ legacy/2014/07/23/06-16-2010.pdf [https://perma.cc/MAA4-HMHF]. Although the Justice Department did not seek certiorari in SpeechNow, the plaintiffs did. They maintained that independent expenditure committees should not be required to register as political committees. The Justice Department filed a brief in opposition to the plaintiffs' petition for certiorari. See generally Brief for the Respondent in Opposition, Keating v. FEC, 562 U.S. 1003 (2010) (No. 10-144). In Keating, the court denied a writ of certiorari to review SpeechNow. Keating, 562 U.S. 1003.

37. See Victor Navasky, Tomorrow Never Knows, N.Y. Times MAG. (Sept. 29, 1996), http://www.nytimes.com/1996/09/29/magazine/tomorrow-never-knows.html

[https://perma.cc/2RDT-VD9D]; see also id. (reporting Albert Einstein's 1932 statement that "there is not the slightest chance that [nuclear] energy will ever be obtainable").

38. See 2016 Outside Spending, by Super PAC, OpENSECRETS.ORG, https://www.opensecrets.org/outsidespending/summ.php?cycle=2016\&chrt=V\&disp=O\&typ $\mathrm{e}=\mathrm{S}$ [https://perma.cc/Q3YV-M8YM] (last visited Mar. 15, 2018).

39. See 2016 Super PACs: How Many Donors Give?, OpenSeCrets.org, https://www.opensecrets.org/outsidespending/donor_stats.php?cycle=2016\&type =B [https://perma.cc/9VQC-42R4] (last visited Mar. 15, 2018) (discussing both individuals and organizations).

40. See 2016 Super PACs: How Many Donors Give?, OPEnSECRETS.ORG, https://www.opensecrets.org/outsidespending/donor_stats.php?cycle=2016\&type=I [https://perma.cc/FK23-SP7Y] (last visited Mar. 15, 2018) (discussing only individuals).

41. See 2016 Top Donors to Outside Spending Groups, OpENSECRETS.ORG, https://www.opensecrets.org/outsidespending/summ.php?cycle=2016\&disp=D\&type=V\&su peronly=S [https://perma.cc/8ZMV-MFR2] (last visited Mar. 15, 2018). 
contributed by the top one hundred donors was $\$ 7.7$ million. ${ }^{42}$ What Attorney General Holder called "a small subset of federally regulated contributions" had become the creature that ate federal election law.43 Although eight years have passed since SpeechNow, the Supreme Court has not decided whether Congress's limits on contributions to super PACs are valid.

This Article offers three criticisms of the SpeechNow syllogism:

(1) The syllogism is fallacious. Contributions to super PACs can corrupt even when expenditures by these groups do not.

(2) The major premise of the syllogism-Citizens United's statement that independent expenditures do not corrupt—was dictum, a nonbinding aside.

(3) Other statements in the Citizens United opinion and a Supreme Court decision shortly before Citizens United make clear that the Supreme Court did not mean that independent expenditures do not corrupt at all.

Following this Article's criticism of the SpeechNow syllogism, it considers an argument for the D.C. Circuit's ruling that the D.C. Circuit did not make. In separate opinions twenty-two years apart, Justice Blackmun and Justice Kennedy suggested that the distinction between contributions and expenditures is a distinction between contributions to candidates (broadly defined as donations whose spending candidates can influence) and all other forms of campaign financing. 44 In their view, candidates cannot be corrupted by funds whose expenditure they do not control. These Justices regarded contributions to independent-expenditure groups not as contributions but as expenditures.

Plurality opinions and one majority opinion have rejected this view. 45 Moreover, as this Article shows, this argument for the SpeechNow result misses the reasons the Supreme Court distinguished contributions from expenditures. The Court did not endorse the untenable view that candidates and officeholders cannot be corrupted by contributions that others spend on their behalf.

Buckley instead pointed to a number of differences between contributions and expenditures. One difference was that funds whose expenditure a candidate controls are likely to be more valuable to him than funds spent by others on his behalf. 46 Another, however, was that "the transformation of contributions into political debate involves speech by someone other than the contributor."47 A review of all the concerns that prompted the Supreme

42. Id.

43. See Letter from Eric H. Holder, Jr., supra note 36.

44. McConnell v. FEC, 540 U.S. 93, 290-301 (2003) (Kennedy, J., concurring in part and dissenting in part), overruled in part by Citizens United v. FEC, 558 U.S. 310 (2010); Cal. Med. Ass'n v. FEC, 453 U.S. 182, 203 (1981) (Blackmun, J., concurring in part).

45. See McConnell, 540 U.S. at 152 (majority opinion); Cal. Med. Ass'n, 453 U.S. at 19399 (plurality opinion); Colo. Republican Fed. Campaign Comm. v. FEC (Colorado I), 518 U.S. 604, 617 (1996) (plurality opinion).

46. Buckley v. Valeo, 424 U.S. 1, 47 (1976) (per curiam).

47. Id. at 21 . 
Court to distinguish between contributions and expenditures shows that contributions to super PACs differ from the expenditures whose restriction the Court struck down. Contributions to super PACs, however, cannot reasonably be distinguished from the contributions to candidates whose restriction the Court upheld. Super PAC contributions are indeed contributions.

After addressing the SpeechNow syllogism and exploring the reasons for the Supreme Court's distinction between contributions and expenditures, this Article focuses on the ultimate question posed by Buckley. Do unlimited super PAC contributions create a sufficient appearance of quid pro quo corruption to justify congressional restriction? The appearance of corruption created by these contributions is in fact intense, pervasive, and reasonable. SpeechNow has sharpened class divisions and helped to tear America apart.

After explaining why limits on contributions to super PACs should survive Citizens United, this Article examines the difficulty of bringing the issue before the Supreme Court. It describes the efforts of this Article's authors, other lawyers, members of Congress, candidates for Congress, and the public-interest organization Free Speech for People to secure an authoritative Supreme Court resolution of the question.

\section{THE DEFICIENCIES OF SPEECHNOW}

\section{A. SpeechNow's Supposed Syllogism Is Fallacious}

Although SpeechNow concluded that "contributions to groups that make only independent expenditures . . . cannot corrupt," 48 a federal grand jury took a different view when, in 2015, it indicted U.S. Senator Robert Menendez and Dr. Solomon Melgen for bribery.

The indictment alleged that Dr. Melgen made two \$300,000 contributions to a super PAC supporting Senator Menendez's reelection. According to the indictment, he made these contributions "in return for Mendendez's advocacy at the highest levels of [two federal agencies] on behalf of Melgen in his Medicare billing dispute." 49

Menendez and Melgen moved to dismiss the charges based on the super PAC contributions. They maintained that "no quid pro quo corruption can arise when a private citizen contributes to a bona fide Super PAC, because a bona fide Super PAC does not coordinate its expenditures with a candidate."50 A federal court denied the motion to dismiss, noting that the federal bribery statute forbids corruptly seeking "anything of value personally or for any other person or entity, in return for being influenced in the performance of any official act.”51 The court quoted a Seventh Circuit decision: "A participant in a scheme to defraud is guilty even if he is an

48. SpeechNow.org v. FEC, 599 F.3d 686, 694 (D.C. Cir. 2010) (en banc).

49. Indictment at 61-63, United States v. Menendez, 132 F. Supp. $3 d 635$ (D.N.J. 2015) (No. 15-155), 2015 WL 1457957 (counts fifteen through eighteen).

50. Menendez, 132 F. Supp. 3d at 639.

51. Id. at 640 (quoting 18 U.S.C. § 201(b)(2) (2012)). 
altruist and all the benefits of the fraud accrue to other participants."52 Just as a public official cannot escape a bribery conviction by saying, "Please pay the money to my sister," he cannot avoid conviction by saying, "Please pay the money to my alter-ego super PAC."

After a jury failed to reach a verdict on the charges against Menendez and Melgen, the trial court again rejected the defendants' contention that a contribution to a super PAC cannot be a bribe. 53 The court noted, however, that neither a super PAC contribution nor a contribution to a candidate can be a bribe in the absence of an "explicit" quid pro quo.54 Because the government's evidence at trial did not establish an explicit quid pro quo, the court dismissed the charges based on Melgen's political contributions.55 Its dismissal led the government to announce that it would not retry the defendants on the other charges. 56

Menendez and Melgen avoided conviction, but a case in which a candidate expressly promises official action in exchange for a super PAC contribution reveals the senselessness of the bottom line of the SpeechNow opinion: "[C]ontributions to groups that make only independent expenditures... cannot corrupt ....”57 Designating an independent expenditure group as an official's beneficiary cannot legalize bribe-taking, and it cannot make bribetaking a First Amendment right.

A super PAC contribution given in return for official favors will be spent in the same way as other contributions. It will buy advertisements and bring information to the public. This contribution is no less "speech" than any other contribution. If it were true that "contributions to groups that make only independent expenditures . . . cannot corrupt," the government would have no interest in regulating this speech. It could no more restrict super PAC contributions through the law of bribery than it could through campaign finance law.

The question remains whether the D.C. Circuit fairly disclaimed responsibility for its unfounded conclusion by pointing to the Supreme Court. Did this conclusion follow ineluctably from Citizens United's declaration that "independent expenditures . . . do not give rise to corruption or the appearance of corruption”?58

Notice that the Menendez-Melgen indictment did not allege that the super PAC that received Melgen's funds did anything wrong or that its expenditures corrupted Menendez. Contrary to the analysis of the D.C.

52. Id. (quoting United States v. Spano, 421 F.3d 599, 603 (7th Cir. 2005)).

53. United States v. Menendez, No. 15 Cr. 155, 2018 WL 526746, at *9-11 (D.N.J. Jan. 24, 2018).

54. Id. at *11-12; see also infra notes 194-97 and accompanying text.

55. Menendez, 2018 WL 526746, at *11-12.

56. Nick Corasaniti, Justice Department Moves to Dismiss Corruption Case Against Menendez, N.Y. TiMES (Jan. 31, 2018), https://www.nytimes.com/2018/01/31/nyregion/ justice-department-moves-to-dismiss-corruption-case-against-menendez.html [http://perma.cc/8CZM-QKVQ].

57. SpeechNow.org v. FEC, 599 F.3d 686, 694 (D.C. Cir. 2010) (en banc).

58. Citizens United v. FEC, 558 U.S. 310, 357 (2010). 
Circuit, super PAC contributions can corrupt even when these groups' expenditures do not. The SpeechNow syllogism is fallacious.

Of course a contribution to a super PAC might turn out to have little value to a candidate if the super PAC never spent it. The corrupting effect of a contribution, however, does not depend on the purposes for which it is spent or whether it is spent at all. A senator who agreed to vote in favor of widget subsidies in exchange for a widget maker's donation to the Red Cross might see little value in the donation unless the Red Cross put this donation to use. Even if the Red Cross never spent the donation, however, the senator and the widget maker would be guilty of bribery. Moreover, if the Red Cross did use the donation for the benevolent purposes the senator sought to advance, the D.C. Circuit probably would not say that, because the Red Cross's expenditures did great good and did not corrupt anyone, the widget maker's contribution could not corrupt either.59

The Federal Election Commission has acquiesced in the SpeechNow decision and is currently resisting a legal challenge to SpeechNow by members of Congress and congressional candidates.60 Even the FEC, however, apparently recognizes that super PAC contributions can corrupt. A federal statute forbids political contributions by government contractors, 61 and the FEC recently sanctioned a contractor for violating this statute although the only group to which it contributed was a super PAC supporting the presidential candidacy of Hillary Clinton. 62

This super PAC no doubt used the money it received from the government contractor in the same way as its other dollars. If the legitimacy of a group's expenditures established the legitimacy of the contributions it received, contributions by government contractors could not be proscribed. Even donations by Vladimir Putin and Kim Jong-un would be constitutionally protected. There are good reasons for prohibiting political contributions by government contractors and the leaders of foreign governments, and Congress has prohibited them.63 But one cannot plausibly distinguish more corrupting from less corrupting contributions while insisting that, as a matter

59. The SpeechNow syllogism seems to rest on the proposition that the greater includes the lesser. If a super PAC's final products (expenditures) do not corrupt, the components of these products (contributions) cannot corrupt either. But super PAC contributions can corrupt before they become part of the final product. They can corrupt even if they are never spent because a super PAC manager absconds with them to Rio.

60. This Article describes the FEC's resistance infra Part IV.

61. 52 U.S.C. § 30119(a)(1) (2012).

62. MUR \#7099: Suffolk Construction Company, Inc., Fed. ELECTION COMM’N, https://www.fec.gov/data/legal/matter-under-review/7099/ [https://perma.cc/5PZP-DP5S] (last visited Mar. 15, 2018). In this case file, see especially the First General Counsel's Report of February 14, 2017, and the Conciliation Agreement of September 25, 2017.

63. See 52 U.S.C. § 30119(a)(1) (prohibiting political contributions by government contractors); id. $\S 30121$ (prohibiting political contributions and expenditures by foreign nationals); Bluman v. FEC, 565 U.S. 1104 (2012) (mem.) (upholding Congress's ban on contributions and expenditures by foreign nationals), aff'g 800 F. Supp. 2d 281 (D.D.C. 2011). Applying either ban to super PAC contributions would be incompatible with the reasoning of SpeechNow. 
of logic and law, contributions to independent-expenditure groups cannot corrupt at all.

Like the FEC, a three-judge federal district court in the District of Columbia recently rejected the SpeechNow syllogism. 64 In an opinion by Circuit Judge Sri Srinivasan, the court declared that even when a political party's soft-money expenditures are independent of any candidate and do not corrupt, contributions to the party for the purpose of making these expenditures do corrupt: "[T]he inducement occasioning the prospect of indebtedness on the part of a federal officeholder is not the spending of money by the political party. The inducement instead comes from the contribution of soft money to the party in the first place."65 The court sought to distinguish SpeechNow by suggesting that the ties between candidates and parties are closer than those between candidates and super PACs.66 But SpeechNow did not offer this empirical judgment; it rested on a supposedly compelling logical deduction — one that the three-judge court plainly did not accept. The Supreme Court summarily affirmed the three-judge court's decision. 67

Corruption by contribution rather than expenditure is what happens in practice. It is the six-, seven-, and eight-figure donations to super PACs that create the appearance (and likely the reality) of corruption, not the groups' expenditures. When an op-ed writer complains that the government has become "like a corporation, with the richest 0.001 percent buying shares and demanding board seats,"68 he speaks of donors to super PACs, not of the operatives who determine how their funds are spent. People who decry the influence of David and Charles Koch, 69 Sheldon Adelson,70 George Soros, 71 and George Clooney 72 probably do not know the names of the managers who receive and spend these donors' funds. It is the check writers, not the money spenders, who may have given America its sugar subsidies, its special tax

64. Republican Party of La. v. FEC, 219 F. Supp. 3d 86, 98 (D.D.C. 2016), aff'd, 137 S. Ct. 2178 (2017) (mem.).

65. Id. at 97.

66. Id. at 98 .

67. Republican Party of La. v. FEC, 137 S. Ct. 2178 (2017) (mem.). Justices Thomas and Gorsuch-but notably, not Chief Justice Roberts and Justices Kennedy and Alito-dissented from the Court's affirmance and would have set the case for argument. Id.

68. David M. Magerman, When a Hedge Fund Billionaire 'Buys' Democracy, PHILA. INQUIRER (Mar. 1, 2017, 10:55 AM), http://www.philly.com/philly/blogs/inq-phillydeals/ Billionaires_and_Democracy_Magerman_Mercer_Renaissance_Trump_Bannon_Conway.ht ml [https://perma.cc/J85U-6WAN].

69. See generally JANE MAYer, DARK MONey: THE HidDen History OF THE BillionAiRES BEHIND THE RISE OF THE RADICAL Right (2016) (describing the political activity of the Koch brothers and its impact).

70. See, e.g., Sheldon Adelson's Billions Shape U.S. Politics as Many Question His Influence, GUARDIAN (Nov. 1, 2012, 2:07 PM), https://www.theguardian.com/world/ 2012/nov/01/sheldon-adelson-billions-politics-influence [https://perma.cc/ZE3H-JRSL].

71. See, e.g., Richard Larsen, This Is Why We Should Fear George Soros, Not the Koch Brothers, W. JOURNALISM (Apr. 10, 2014, 10:17 AM), http://www.westernjournalism.com/ koch-brothers-george-soros-fear/ [https://perma.cc/765N-3EJP].

72. See, e.g., George Clooney Wants You to BELIEVE He Doesn't Buy Political Influence, BuzzKIX.COM (Oct. 3, 2016), http://buzzkix.com/george-clooney-wants-you-to-believe-hedoesnt-buy-political-influence/ [https://perma.cc/QCU4-2C32]. 
treatment of carried interest, and its armaments approved by Congress despite opposition by the Pentagon. A campaign finance system like the one authorized by Buckley - one in which contributions are limited but in which candidates, parties, and super PACS may spend whatever they receivewould notably limit corruption. As Buckley observed, "The interest in alleviating the corrupting influence of large contributions is served by the Act's contribution limitations and disclosure provisions rather than... campaign expenditure ceilings.”73

\section{B. The Statement upon Which the D.C. Circuit Relied Was Dictum}

SpeechNow characterized Citizens United's statement that independent expenditures do not corrupt as something the Supreme Court had held as a matter of law. 74 The Court's statement, however, was dictum.

Citizens United was argued twice. After the initial argument, the Court restored the case to the docket and ordered the parties to address an issue they had not previously considered.75 Two of the Court's earlier decisions had held that political speech could be restricted simply because the speaker was a corporation. 76 The Court asked whether these decisions should be overruled.

The first part of the Citizens United opinion did overrule the earlier decisions. It held that a group's speech cannot be restricted simply because the group is incorporated.77 The Supreme Court declared that the First Amendment prohibits "restrictions distinguishing among different speakers, allowing speech by some but not by others."78 It found "no basis for the proposition that, in the context of political speech, the Government may impose restrictions on certain disfavored speakers."79 It noted that "[s]peech restrictions based on the identity of the speaker are all too often simply a means to control content." 80 It concluded that "the Government cannot restrict political speech based on the speaker's corporate identity."81

This holding fully resolved the case before the Court. A statute restricted a group's political expenditures only because the group was a corporation. This statute was unconstitutional. However strong the government's regulatory interest might have been, the government could not advance this interest by limiting only corporate speech. The case seemed over.

The Supreme Court, however, did not stop. It noted that Buckley v. Valeo had regarded only one interest as "sufficiently important" to justify limiting

73. Buckley v. Valeo, 424 U.S. 1, 55 (1976) (per curiam).

74. SpeechNow.org v. FEC, 599 F.3d 686, 694 (D.C. Cir. 2010) (en banc).

75. Citizens United v. FEC, 557 U.S. 932 (2009) (No. 08-205) (order restoring the case to the calendar for reargument).

76. See McConnell v. FEC, 540 U.S. 93, 203-09 (2003), overruled in part by Citizens United v. FEC, 558 U.S. 310 (2010); Austin v. Mich. State Chamber of Commerce, 494 U.S. 652, 658-60 (1990), overruled by Citizens United, 558 U.S. 310.

77. Citizens United, 558 U.S. at 346.

78. Id. at 340 .

79. Id. at 341.

80. Id. at 340 .

81. Id. at 346. 
campaign contributions and expenditures - " the prevention of corruption and the appearance of corruption." 82 It added, "When Buckley identified a sufficiently important governmental interest in preventing corruption or the appearance of corruption, that interest was limited to quid pro quo corruption."83 The Court concluded, "The anticorruption interest is not sufficient to displace the speech here in question." 84 This statement fully resolved the case before the Court a second time.

Either branch of the Citizens United opinion would have sufficed without the other. Once the Court held that the government may not restrict independent expenditures on the basis of corporate identity, there was no reason for it to consider whether the government may restrict independent expenditures at all. And if the Court had said initially that independent expenditures are insufficiently corrupting for Congress ever to restrict them, there would have been no reason for it to consider whether this speech-related activity may be restricted on the basis of corporate identity.

Offering both conclusions at once contravened the familiar principle that a court should not decide constitutional issues in advance of necessity. 85 This principle means among other things that a court should not make two constitutional rulings when one will do. As Chief Justice Roberts observed before joining the Supreme Court, "[I]f it is not necessary to decide more, it is necessary not to decide more." 86

Even after resolving the case twice, the Supreme Court did not stop. Three sentences after it declared, "The anticorruption interest is not sufficient to displace the speech here in question," it offered the statement that drove the SpeechNow decision: "[W]e now conclude that independent expenditures ... do not give rise to corruption or the appearance of corruption."87 The Court's initial statement declared the anticorruption interest insufficient to support a restriction of independent expenditures, but the D.C. Circuit read the second statement as declaring this interest nonexistent. So interpreted, the statement went far beyond any issue before the Court.

If the Court had offered only its initial formulation, the D.C. Circuit could not have written the opinion it wrote in SpeechNow. The major premise of the court's syllogism would not have existed. The court could not have declared that "the [Supreme] Court held that the government has no anticorruption interest in limiting independent expenditures." 88 It could not have relied on the proposition that "something . . . outweighs nothing every time."89 The court instead would have been required to assess the strength

82. Id. at 345 (quoting Buckley v. Valeo, 424 U.S. 1, 25-26 (1976) (per curiam)).

83. Id. at 359.

84. Id. at 357.

85. See, e.g., Ashwander v. Tenn. Valley Auth., 297 U.S. 288, 346 (1936) (Brandeis, J., concurring).

86. PDK Labs., Inc. v. DEA, 362 F.3d 786, 799 (D.C. Cir. 2004) (Roberts, J., concurring in part).

87. Citizens United, 558 U.S. at 357.

88. SpeechNow.org v. FEC, 599 F.3d 686, 693 (D.C. Cir. 2010) (en banc).

89. Id. at 695 (alteration in original) (quoting Nat'l Ass'n of Retired Fed. Emps. v. Horner, 879 F.2d 873, 879 (D.C. Cir. 1989)). 
of the government's regulatory interest, recognizing that an interest too weak to justify a restriction of expenditures can justify a restriction of contributions.

In a decision that followed Citizens United, four dissenting Justices criticized Citizens United's description of the kind of corruption needed to justify a restriction of independent expenditures. 90 They observed that the Court's language should be regarded "as dictum, as an overstatement, or as limited to the context in which it appears."91 These Justices were correct. Indeed, the statement that became a major premise of the SpeechNow syllogism was not merely dictum; it was dictum twice over.

\section{The Supreme Court Did Not Mean Its Dictum Literally}

One might take a conspiratorial view of Citizens United's ambiguous declaration that independent expenditures do not corrupt. Perhaps five Justices of the Supreme Court, realizing that Justices with their perspective might not constitute a majority of the Court forever, reached out to resolve issues not before them, including the issue that soon came before the D.C. Circuit in SpeechNow. Perhaps these activist Justices truly meant to say that independent expenditures do not corrupt even a smidgen, and perhaps they swept so expansively in a calculated effort to control the future. We doubt, however, that the Justices in the majority had any such grand or devious strategy. It seems more likely that they did not mean their dictum to be taken in the way the D.C. Circuit took it.

The Supreme Court slipped easily from its declaration that independent expenditures are insufficiently corrupting as to justify their restriction to its declaration that these expenditures do not corrupt at all. Under Buckley's two-tiered standard of review, these two statements have different consequences, but the Court gave no sign that it recognized any notable difference between them. 92

The Court again indicated that it failed to notice any important difference between its two formulations when it attributed the stronger of these formulations to Buckley. It wrote, “This confirms Buckley's reasoning that independent expenditures do not lead to, or create the appearance of, quid pro quo corruption."93 Buckley, however, had said no such thing. It had endorsed only the weaker formulation: "We find that the governmental interest in preventing corruption and the appearance of corruption is

90. McCutcheon v. FEC, 134 S. Ct. 1434, 1471 (2014) (Breyer, J., joined by Ginsburg, Sotomayor, and Kagan, JJ., dissenting).

91. Id.

92. Slight literary imprecision can have huge consequences. See, e.g., O’Connor v. Oakhurst Dairy, 851 F.3d 69, 75 (1st Cir. 2017) (concluding that the absence of a comma before the final item in a statutory series required an award of overtime pay that would not have been allowed if the comma had been present); Daniel Victor, Lack of Oxford Comma Could Cost Maine Company Millions in Overtime Dispute, N.Y. Times (Mar. 16, 2017), https://www.nytimes.com/2017/03/16/us/oxford-comma-lawsuit.html?_r=0 [https://perma.cc/S6FV-6CC5].

93. Citizens United v. FEC, 558 U.S. 310, 360 (2010). 
inadequate to justify § 608(e)(1)'s ceiling on independent expenditures.”94 And again: "The independent advocacy restricted by the provision does not presently appear to pose dangers of real or apparent corruption comparable to those identified with large campaign contributions."95

Before Citizens United, two of the Justices who joined the majority opinion expressly recognized that independent expenditures can corrupt. In FEC $v$. Wisconsin Right to Life, Inc., 96 Chief Justice Roberts, joined by Justice Alito, declared, "[I]t may be that, in some circumstances, 'large independent expenditures pose the same dangers of actual or apparent quid pro quo arrangements as do large contributions.'”97 In fact, Justice Roberts noted, "We have suggested that this interest might... justify limits on electioneering expenditures. ..."98

Probably the clearest indication that the Court did not mean its dictum literally is that this statement, if taken literally, would be inconsistent with a ruling the Court made less than a year before it decided Citizens United. In Caperton v. A.T. Massey Coal Co.,99 the Court considered the effect of political contributions and expenditures made by the chief executive officer of the Massey Coal Company, Don Blankenship. The Court's opinion was by Justice Kennedy, the same Justice who wrote the opinion in Citizens United.100

After a jury returned a $\$ 50$ million verdict against Massey, Blankenship spent more than \$3 million to prevent the reelection of a justice of the state supreme court that would hear Massey's appeal. The incumbent justice was defeated, and his replacement provided the decisive vote for reversing the $\$ 50$ million verdict against Massey.

The Supreme Court held that the newly elected justice's refusal to recuse himself from the coal company's appeal violated the Due Process Clause. Justice Kennedy wrote for the Court, "We conclude that there is a serious risk of actual bias ... when a person with a personal stake in a particular case had a significant and disproportionate influence in placing the judge on the case by raising funds ... when the case was pending or imminent."101 Citizens United distinguished Caperton by noting that Caperton's "holding was limited to the rule that the judge must be recused, not that the litigant's political speech could be banned.”102

Judicial recusal and limiting independent expenditures are indeed different remedies, and Caperton's ruling that the Constitution required one of these remedies was consistent with Citizens United's ruling that the Constitution prohibited the other. If Blankenship's expenditures did "not give rise to

94. Buckley v. Valeo, 424 U.S. 1, 45 (1976) (per curiam) (emphasis added).

95. Id. at 46 (emphasis added).

96. 551 U.S. 449 (2007).

97. Id. at 478 (quoting Buckley, 424 U.S. at 45).

98. Id. (emphasis in original).

99. 556 U.S. 868 (2009).

100. Justice Kennedy was in fact the only Justice to join both five-to-four decisions.

101. Caperton, 556 U.S. at 884.

102. Citizens United v. FEC, 558 U.S. 310, 360 (2010). 
corruption or the appearance of corruption," however, why was any remedy required? Could these expenditures have produced "a serious risk of actual bias" without giving rise to even an appearance of corruption? A near army of commentators have observed that Caperton's holding is inconsistent with Citizens United's statement that "independent expenditures . . . do not give rise to corruption or the appearance of corruption."103

When the Supreme Court has spoken carelessly and without fully considering the implications of a statement, lower courts and the Court itself have found ways to say, with the legendary comedian Gilda Radner, "never mind.” For example, early in the Citizens United opinion, the Court declared that the First Amendment prohibits "restrictions distinguishing among different speakers, allowing speech by some but not by others."104 The Court apparently referred to all forms of speech, including political contributions and expenditures. Two years after Citizens United, however, the Court summarily affirmed a lower court decision upholding a ban on political contributions and expenditures by noncitizens who are not permanent residents of the United States. 105 The Court's statement that the government may not restrict speech on the basis of a speaker's identity evidently had become inoperative. 106

Citizens United said more narrowly, "[T]he Government cannot restrict political speech based on the speaker's corporate identity."107 This statement in fact appeared to be Citizens United's holding. Taking the Court's statement literally, however, would give corporations the same right as individuals to contribute to candidates, and the number of corporations an individual can form is unlimited. A person should not be able to contribute 101 times the individual contribution limit simply because he has created 100 corporations. Perhaps the Court did not consider fully the implications of its statement.

103. See, e.g., Nicholas Almendares \& Catherine Hafer, Beyond Citizens United, 84 FordHAM L. REV. 2755, 2768-71 (2016); Richard Briffault, Corporations, Corruption, and Complexity: Campaign Finance After Citizens United, 20 CoRnELl J.L. \& PuB. PoL'y 643, 659-60 (2011); Richard L. Hasen, Citizens United and the Illusion of Coherence, 109 MicH. L. REv. 581, 584 (2011); Larry Howell, Once Upon a Time in the West: Citizens United, Caperton, and the War of the Copper Kings, 73 MonT. L. REv. 25, 54-57 (2012); Anthony Johnstone, A Madisonian Case for Disclosure, 9 GEO. MASON L. REv. 413, 437-38 (2012); Michael S. Kang, The End of Campaign Finance Law, 98 VA. L. REv. 1, 45-47 (2012); Justin Levitt, Confronting the Impact of Citizens United, 29 YALE L. \& POL’y ReV. 217, 230 (2010); Adam Liptak, Caperton After Citizens United, 52 ARIZ. L. Rev. 203, 203 (2010); Burt Neuborne, Felix Frankfurter's Revenge: An Accidental Democracy Built by Judges, 2011 N.Y.U. Rev. L. \& Soc. Change 602, 659-60; Alexander Polikoff, So How Did We Get into This Mess?: Observations on the Legitimacy of Citizens United, 105 Nw. U. L. REv. ColloquY 203, 221-22 (2011); James Sample, Democracy at the Corner of First and Fourteenth: Judicial Campaign Spending and Equality, 66 N.Y.U. ANN. SuRV. AM. L. 727, 729-30 (2011).

104. Citizens United, 558 U.S. at 340.

105. Bluman v. FEC, 565 U.S. 1104 (2012) (mem.), aff'g 800 F. Supp. 2d 281, 282-83 (D.D.C. 2011).

106. See Inoperative, SAfire’s Political Dictionary 346 (rev. ed. 2008) (defining inoperative as "a correction without an apology, leaving the corrector in a deep hole").

107. Citizens United, 558 U.S. at 346. 
After Citizens United, four federal courts of appeals upheld Congress's century-old prohibition of political contributions by corporations, 108 and the Supreme Court denied certiorari in two of the cases.109 The declaration that "the Government cannot restrict political speech based on the speaker's corporate identity" also seemed to have become inoperative.

Lower courts and the Supreme Court itself have tempered a literal reading of Citizens United's broad pronouncements with common sense. The D.C. Circuit should have done the same thing in SpeechNow. Instead, the court based its analysis of whether the Constitution guarantees the right to give \$10 million to a super PAC entirely on an imprecise Supreme Court dictum. The court read this statement for all it might be worth and then some. The Supreme Court's dictum supplied the only support the lower court offered for its conclusion that contributions to super PACs cannot corrupt-not even a scintilla and not even when they lead to federal indictments for bribery.

\section{THE DIFFERENCES BETWEEN CONTRIBUTIONS AND EXPENDITURES}

\section{A. Supreme Court Precedents}

In three cases, various Supreme Court Justices have spoken to the issue that the D.C. Circuit decided in SpeechNow-the validity of limiting contributions to groups that make only independent expenditures. In one of these cases, the Court itself upheld limits on contributions to political parties to make independent expenditures, thus repudiating the SpeechNow syllogism.

In California Medical Ass'n v. FEC,110 the Court upheld a limit on what a medical association could contribute to a PAC that made both independent expenditures and contributions to candidates - a conventional PAC, not a super PAC.111 Four dissenting Justices would not have reached the issue; they maintained that the Supreme Court lacked jurisdiction to hear the case. 112

The other five Justices upheld the contribution limit, but Justice Blackmun wrote in a concurring opinion that, if the PAC had been a super PAC rather than a conventional PAC, he would have voted to strike the limit down: "[A]

108. Minn. Citizens Concerned for Life, Inc. v. Swanson, 692 F.3d 864, 877-80 (8th Cir. 2012) (en banc); United States v. Danielczyk, 683 F.3d 611, 617 (4th Cir. 2012); Ognibene v. Parkes, 671 F.3d 174, 183-84 (2d Cir. 2012); Thalheimer v. City of San Diego, 645 F.3d 1109, 1124-27 (9th Cir. 2011); Green Party of Conn. v. Garfield, 616 F.3d 189, 199 (2d Cir. 2010); see also Tillman Act, Pub. L. No 59-36, ch. 420, 34 Stat. 864, 864-65 (1907) (forbidding political contributions by corporations); FEC v. Beaumont, 539 U.S. 146, 152 (2003) (upholding the ban on contributions by corporations-a decision that Citizens United did not discuss and probably did not mean to overrule).

109. Danielczyk v. United States, 568 U.S. 1193 (2013) (denying certiorari in Danielczyk, 683 F.3d 611); Ognibene v. Parkes, 567 U.S. 935 (2012) (denying certiorari in Ognibene, 671 F.3d 174).

110. 453 U.S. 182 (1981).

111. Id. at 201.

112. Id. at 207-08 (Stewart, J., dissenting). 
different result would follow if [the contribution limit] were applied to contributions to a political committee established for the purpose of making independent expenditures, rather than contributions to candidates."113

The other four Justices who reached the merits did not join Justice Blackmun's opinion, apparently because they took a different view. Buckley treated contributions as low-value speech partly because "the transformation of contributions into political debate involves speech by someone other than the contributor." 114 The plurality opinion quoted this language, italicizing the words "speech by someone other than the contributor."115 It observed that, although the medical association created the PAC to which it contributed, the PAC's speech was not the association's,116 and it declared, “'[S]peech by proxy' ... is not the sort of political advocacy that this Court in Buckley found entitled to full First Amendment protection."117 The plurality's analysis was as applicable to contributions to super PACs as it was to contributions to conventional PACs and to candidates.

In Colorado Republican Campaign Committee v. FEC (Colorado I), 118 the Supreme Court struck down a limit on expenditures by a political party. The principal opinion by Justice Breyer, joined by Justices O'Connor and Souter, concluded that these expenditures were not coordinated with those of any candidate. The opinion recognized, however, that, by contributing to an independent expenditure group like the party, donors could evade the limits on contributions to candidates. Justice Breyer accordingly had no doubt that limits on contributions to independent-expenditure groups were valid:

The greatest danger of corruption . . . appears to be from the ability of donors to give sums up to $\$ 20,000$ to a party which may be used for independent ... expenditures for the benefit of a particular candidate. We could understand how Congress, were it to conclude that the potential for evasion of the individual contribution limits was a serious matter, might decide to change the statute's limitations on contributions to political parties. ... But we do not believe that the risk of corruption present here could justify the "markedly greater burden on basic freedoms caused by" the statute's limitations on expenditures. 119

In the most significant case of the trilogy, McConnell v. FEC,120 the Court itself addressed the issue. McConnell upheld limits on the contribution of "soft money" to political parties - money the parties used for such purposes as turning out voters rather than advocating the election of identified candidates.121 The Court recited evidence that candidates valued and

113. Id. at 203 (Blackmun, J., concurring in part).

114. Buckley v. Valeo, 424 U.S. 1, 21 (1976) (per curiam).

115. Cal. Med. Ass'n, 453 U.S. at 197 (plurality opinion) (quoting Buckley, 424 U.S. at 21).

116. Id. at 196.

117. Id.

118. 518 U.S. 604 (1996).

119. Id. at 617 (Breyer, J.) (quoting Buckley, 424 U.S. at 44).

120. 540 U.S. 93 (2003), overruled in part by Citizens United v. FEC, 558 U.S. 310 (2010).

121. Id. at 101. McConnell also upheld Congress's prohibition of electioneering communications by corporations and labor unions. Id. at 203-09. Citizens United overruled McConnell on this point, but it did not question McConnell's holding that limits on soft-money 
encouraged soft-money contributions (just as they now value and encourage super PAC contributions), but nothing in McConnell indicated that softmoney expenditures were coordinated with expenditures made by the candidates' own campaigns.

In dissent, Justice Kennedy argued that the lack of coordination was crucial. As the majority summarized his view, Congress could restrict only "contributions made at the express behest of, and expenditures made in coordination with, a federal officeholder or candidate.”122 Justice Kennedy wrote, "[I]ndependent party activity, which by definition includes independent receipt and spending of soft money, lacks a possibility for quid pro quo corruption of federal officeholders.”123 His view would block Congress from limiting soft-money contributions to parties and also would block Congress from limiting contributions to super PACs unless they were made at the behest of a candidate. The Court, however, in an opinion written jointly by Justice Stevens and Justice O’Connor, rejected Justice Kennedy’s position, calling it "crabbed" and declaring that it ignored "precedent, common sense, and the realities of political fundraising." 124 In the course of its discussion, the Court observed in a footnote that Congress could validly limit contributions made for the purpose of funding "express advocacy and numerous other noncoordinated expenditures.”125

In SpeechNow, the D.C. Circuit made no effort to distinguish limits on contributions to super PACs from the limits on soft-money contributions McConnell upheld.126 After Citizens United, moreover, the Supreme Court reaffirmed McConnell's holding that these contribution limits are valid.127

contributions are valid. Citizens United, 558 U.S. at 319. The Court in fact reaffirmed this central holding of McConnell not long after it decided Citizens United. Republican Nat'l Comm. v. FEC, 561 U.S. 1040 (2010) (mem.), aff'g 698 F. Supp. 2d 150 (D.D.C. 2010).

122. McConnell, 540 U.S. at 152 (citing id. at 290-93, 298-99 (Kennedy, J., dissenting)).

123. Id. at 301 (Kennedy, J., dissenting).

124. Id. at 152 (majority opinion).

125. Id. at 152 n.48; see also FEC v. Mass. Citizens for Life, Inc., 479 U.S. 238, 262 (1986) (noting that if a nonprofit corporation's independent electoral expenditures became sufficiently extensive, the corporation would be subject to various statutory obligations, including the obligation to accept only limited contributions).

126. SpeechNow.org v. FEC, 599 F.3d 686 (D.C. Cir. 2010) (en banc). The court did maintain that Citizens United abandoned McConnell's definition of corruption, id. at 694, and perhaps it believed that McConnell's “soft money” ruling depended on this definition. Lower courts, however, are not free to disregard Supreme Court precedents they believe have been implicitly overruled. See, e.g., Agostini v. Felton, 521 U.S. 203, 237-38 (1997). Moreover, on the same day that the D.C. Circuit decided SpeechNow, a three-judge federal district court in the District of Columbia held that McConnell's approval of the limits on soft money contributions survived Citizens United. Republican Nat'l Comm. v. FEC, 698 F. Supp. 2d 150, 162 (D.D.C. 2010), aff'd, 561 U.S. 1040 (2010) (No. 09-1287). The Supreme Court later summarily affirmed the three-judge court's ruling. Republican Nat'l Comm. v. FEC, 561 U.S. 1040 (2010) (mem.).

A recent decision by another three-judge panel in the District of Columbia maintained that McConnell differed from SpeechNow because the relationship between candidates and parties is closer than that between candidates and super PACs. Republican Party of La. v. FEC, 219 F. Supp. 3d 86, 98 (D.D.C. 2016), aff'd, 137 S. Ct. 2178 (2017) (No. 16-865).

127. See generally Republican Nat'l Comm., 561 U.S. 1040, aff'g 698 F. Supp. 2d 150. Justices Scalia, Kennedy, and Thomas-but notably, not Chief Justice Roberts and Justice Alito-dissented from the Court's summary affirmance. 


\section{B. Are Contributions to Super PACs Really Contributions?}

Although the principal opinions in California Medical Ass' $n$ and Colorado $I$ and the opinion of the Court in McConnell strongly indicate that Congress may limit contributions to independent expenditure groups, Justice Blackmun in California Medical Ass'n and Justice Kennedy in McConnell contended that Congress may limit only contributions to candidates and groups whose spending candidates can influence-in other words, that only contributions to candidates qualify as contributions. When a group's expenditures are coordinated with those of a candidate, the expenditures become contributions to the candidate. ${ }^{128}$ And if expenditures become contributions when they are "coordinated," perhaps contributions become expenditures when they are "uncoordinated" - when no candidate can influence how they are spent. Concluding that contributions to super PACs are not truly contributions - that they are in fact expenditures-would provide an alternate basis for the ruling in SpeechNow. 129

If the distinction between contributions and expenditures rested on the proposition that candidates cannot be corrupted by funds given to and spent by others, this alternate rationale for SpeechNow would make sense. That proposition, however, is plainly false, and it was not in fact the basis for the Supreme Court's distinction.

If the proposition were true, someone would need to tell former Alabama Governor Don Siegelman, who recently spent more than six years in federal prison for bribery. 130 Siegelman allegedly appointed someone to a state board in return for a contribution to a group supporting a referendum he favored - a contribution that did not benefit him personally.131 As this Article noted in its discussion of the charges against Senator Menendez and Dr. Melgen, an official cannot avoid a charge of corruption by saying, "Please pay the money to the Red Cross or my alter-ego super PAC.”132

In Buckley, the Supreme Court did not endorse the untenable view that candidates cannot be corrupted by money paid to and spent by others. Instead it noted several differences between contributions and expenditures. One difference, to be sure, was that money given to a candidate tends to be more corrupting than money spent on his behalf by someone else.

128. See, e.g., 52 U.S.C. § 30116 (a)(7)(B)(i) (2012); Colo. Republican Fed. Campaign Comm. v. FEC (Colorado II), 533 U.S. 431, 438 (2001) ("Expenditures coordinated with a candidate . . . are contributions under the Act.”); Buckley v. Valeo, 424 U.S. 1, 36-37, 46-47, 78 (1976) (per curiam).

129. But see infra note 144 (noting that, even if contributions to super PACs could be regarded as expenditures, many of them could not be regarded as independent expenditures).

130. See Bryan Lyman, Former Alabama Gov. Don Siegelman Released from Prison, MONTGOMERY ADVERTISER (Feb. 8, 2017), http://www.montgomeryadvertiser.com/story/ news/politics/southunionstreet/2017/02/08/former-alabama-gov-don-siegelman-releasedprison/97644094/ [https://perma.cc/92G2-SC6Y].

131. See United States v. Siegelman, 640 F.3d 1159, 1169 n.13 (11th Cir. 2011) (affirming Siegelman's conviction while acknowledging that "contributions to [issue-advocacy campaigns] do not financially benefit the individual politician in the same way that a candidate-election campaign contribution does”).

132. See supra Part I.A. 
The Court offered three reasons for concluding that direct contributions have less communicative value than independent expenditures and two reasons for concluding that contributions are more corrupting. An examination of these reasons reveals that contributions to super PACs are indeed contributions, not expenditures. These contributions cannot reasonably be distinguished from the contributions to candidates whose limitation Buckley upheld.

\section{The Supreme Court's Reasons for Treating Contributions as Low-Value Speech}

All of Buckley's reasons for treating contributions as low-value speech apply fully to contributions to super PACs.

First, the Court said, "A contribution serves as a general expression of support for the candidate and his views, but does not communicate the underlying basis for the support."133 Equally, a contribution to a super PAC does not convey the underlying basis for the contributor's support.

Second, the Court said that "the transformation of contributions into political debate involves speech by someone other than the contributor."134 Transforming a contribution to a super PAC into political debate also "involves speech by someone other than the contributor."

Third, the Court said, limiting the amount of an individual's contribution "permits the symbolic expression of support evidenced by a contribution but does not in any way infringe the contributor's freedom to discuss candidates and issues."135 Again, contributions to super PACs are no different. Limiting a contribution to a super PAC allows the contribution to serve as an expression of support but does not limit a contributor's freedom to discuss candidates and issues.

The strongest of the Court's reasons for treating contributions as low-value speech was probably its observation that transforming contributions into debate "involves speech by someone other than the contributor." Although Buckley rejected the bumper-sticker view that "money is not speech,"136 it recognized that writing a check is not entitled to the same First Amendment protection as actually speaking. The four-Justice plurality in California Medical Ass'n saw this passage of the Buckley opinion as crucial. Their opinion declared, “'[S]peech by proxy” . . . is not the sort of political advocacy that this Court in Buckley found entitled to full First Amendment protection."137

133. Buckley, 424 U.S. at 21.

134. Id.

135. Id.

136. Id. at 15-17. The Court noted that one cannot publish a newspaper or send a telegram without spending money. Justice Alito has called it "very frustrating" for a Supreme Court opinion to be "reduced to a slogan that you put on a bumper sticker." LAURENCE TRIBE \& Joshua Matz, UnCERTAin JustiCE: THE ROBERTS COURT AND THE CONSTITUTION 96 (2014).

137. Cal. Med. Ass'n v. FEC, 453 U.S. 182, 196 (1981) (plurality opinion) (quoting Buckley, 424 U.S. at 21). The weakest of the Court's reasons for treating contributions as lowvalue speech was probably its statement that a contribution limit "permits the symbolic expression of support evidenced by a contribution but does not in any way infringe the 
The Supreme Court's refusal to subject contribution limits to strict scrutiny rested on its conclusion that contributions have limited communicative value. Although the Court discussed the strength of the government's anticorruption interest as well, the intensity of this interest bears on whether a contribution or expenditure limit satisfies strict scrutiny or some other standard, not what the standard should be. As the Court explained in FEC v. Beaumont,138

[T] he level of scrutiny is based on the importance of the "political activity at issue" to effective speech or political association. . . . [R]estrictions on political contributions have been treated as merely "marginal" speech restrictions subject to relatively complaisant review under the First Amendment, because contributions lie closer to the edges than to the core of political expression. 139

Contributions to super PACs have no greater communicative value than contributions to candidates. Like contributions to candidates, these contributions differ from expenditures and "lie closer to the edges than to the core of political expression.”

\section{The Supreme Court's Reasons for Treating Contributions as More Corrupting than Expenditures}

In addition to its three reasons for treating contributions to candidates as low-value speech, Buckley offered two reasons for viewing these contributions as more corrupting than independent expenditures. First, it said, "The absence of prearrangement and coordination of an expenditure with the candidate or his agent ... alleviates the danger that expenditures will be given as a quid pro quo for improper commitments from the candidate.” 140 Second, the Court said that independent expenditures tend to be less valuable to candidates. It wrote, "[I]ndependent advocacy . . . does not presently appear to pose any dangers of real or apparent corruption comparable to those identified with large campaign contributions."141 Moreover, "independent expenditures may well provide little assistance to the candidate's campaign and indeed may prove counterproductive."142

The rules forbidding the coordination of a super PAC's expenditures with those of a candidate limit what advice candidates can give to super PAC

contributor's freedom to discuss candidates and issues.” Buckley, 424 U.S. at 21. The Court elaborated, "The quantity of communication by the contributor does not increase perceptibly with the size of his contribution, since the expression rests solely on the undifferentiated, symbolic act of contributing." Id. A contributor might be surprised to learn that writing a check to a campaign for the maximum permissible amount-a check for thousands of dollars - is merely "symbolic support." Contributions merit a degree of First Amendment protection not only because these contributions constitute symbolic speech by the people who make them but also, and more importantly, because they bring the political speech of others to an audience. The larger the contribution, the more speech it is likely to facilitate (as well as the more illegitimate influence it is likely to have).

138. 539 U.S. 146 (2003).

139. Id. at 161 (citations omitted) (quoting FEC v. Mass. Citizens for Life, Inc., 479 U.S. 238, 259 (1986)).

140. Buckley, 424 U.S. at 47.

141. Id. at 46 .

142. Id. at 47. 
managers, but they do not limit what candidates can say to super PAC donors. If candidates wish to tell donors how they wish super PAC funds to be spent, they may do so freely, as long as the donors do not then act as the candidates' agents by conveying their wishes to the people who will actually determine how the funds are spent.143 And if candidates wish to advise donors how their own funds should be spent-namely, by donating them to the super PAC_-again they may do so within limits. ${ }^{144}$ The possibility of prearrangement and coordination does not distinguish contributions to super PACs from contributions to candidates.

Buckley's claim that the absence of prearrangement and coordination reduces the likelihood of improper commitments by candidates is unconvincing in any event. People willing to violate the law against bribery are usually willing to violate the law forbidding the coordination of electoral expenditures as well. Neither law bars a candidate from meeting with supporters, and when a candidate and a supporter have lunch, they may whisper about coordinating expenditures, bribes, and, if they like, robbing banks. It is difficult to see how the law forbidding the coordination of electoral expenditures reduces the likelihood of bribery in the slightest.145

The more important of Buckley's reasons for regarding independent expenditures as less corrupting than contributions was that expenditures usually have less value to a candidate. Buckley's approval of this reason, however, was tentative: "[I]ndependent advocacy . . . does not presently appear to pose dangers of real or apparent corruption comparable to those identified with large campaign contributions."146 The court added that "independent expenditures may well provide little assistance to the candidate's campaign and indeed may prove counterproductive.”147

Experience in the years since Buckley has called the Court's provisional judgment into question. When Buckley noted that independent expenditures might provide little assistance to a candidate and might prove counterproductive, the Court probably did not foresee super PACs that spend

143. See 11 C.F.R. §§ 109.20(a)-.21(a) (2018).

144. See FEC, Advisory Opinion 2011-12, supra note 9. Even if one were to envision contributions to super PACs as expenditures rather than contributions, many would not be independent expenditures, for federal law allows candidates to encourage donors to make these expenditures. The Federal Election Commission has ruled that a candidate may not request a contribution of more than $\$ 5000$ (the amount of the statutory limit SpeechNow struck down). $I d$. But, when a candidate requests a $\$ 5000$ contribution, a super PAC manager may note the candidate's inability to ask for more and may request a larger contribution himself. The fact that the amount a candidate may request is limited does not distinguish contributions to a super PAC from contributions to the candidate's own campaign.

145. To put the point differently, Buckley maintained that people who observe the law restricting the coordination of electoral expenditures will have limited opportunities to engage in bribery. But if one is willing to assume that people obey the law forbidding the coordination of expenditures, one should also assume that people obey the law against bribery. And, if people obey the law against bribery, the problem vanishes. People who obey the law forbidding coordinated expenditures may have limited opportunities to engage in bribery, but people who obey the law against bribery do not engage in bribery at all.

146. Buckley, 424 U.S. at 46 (emphasis added).

147. Id. at 47 (emphasis added). 
more than the candidates they support, 148 that are managed by candidates' former campaign managers and other experienced political operatives, 149 and that may be ceded responsibility for all of a campaign's advertising. ${ }^{150}$ The Court's judgment that, other things being equal, a candidate would prefer to control campaign expenditures himself is no doubt sound, but post-Buckley experience has suggested that other things often are not equal. There is a strong advantage to having messages sent on one's behalf for which one need take no responsibility.

Without examining post-Buckley experience and without knowing what super PACs would become, Citizens United settled by fiat the empirical question Buckley left open. After declaring the anticorruption interest insufficient to justify any restriction of independent expenditures, 151 it made the sweeping pronouncement that is the focus of much of this Article: "[W]e now conclude that independent expenditures ... do not give rise to corruption or the appearance of corruption."152

Perhaps, as Buckley tentatively postulated and as Citizens United proclaimed, independent expenditures are less corrupting than direct contributions to candidates. Of the five reasons Buckley offered for distinguishing independent expenditures from contributions, only this last one may also distinguish contributions to super PACs from contributions to candidates. A candidate may value a $\$ 5500$ contribution to a super PAC urging his election less than a $\$ 5500$ contribution to his own campaign.

But how much less? In a post-Citizens United decision, McCutcheon $v$. FEC,153 four members of the Citizens United majority joined a plurality opinion written by Chief Justice Roberts. This opinion reiterated Buckley's statement that " $t \mathrm{t}] \mathrm{he}$ absence of prearrangement and coordination of an expenditure with the candidate or his agent ... undermines the value of the expenditure to the candidate" and then acknowledged "[b]ut probably not by 95 percent.”154 Similarly, a candidate might value a \$5500 contribution to a super PAC less than a $\$ 5500$ contribution to his own campaign, but "probably not by 95 percent.” A $\$ 1$ million super PAC contribution produces vastly more corruption or appearance of corruption than a \$5500 campaign

148. See Note, supra note 9, at 1484 ("Super PACs are often able to outspend the candidates they support ....”).

149. See Alschuler, supra note 33, at 394 \& n.23 (noting that the managers of Restore Our Future, the principal super PAC supporting Governor Romney's 2012 presidential campaign, included the political director of Romney's 2008 presidential campaign and the counsel and chief financial officer of Romney's 2008 campaign — and that Priorities USA Action, the principal super PAC supporting President Obama, was also managed by people close to him).

150. See Peter Overby et al., As Bush Campaign Goes Down, the Knives Come Out, NPR (Feb. 23, 2016, 6:00 AM), http://www.npr.org/2016/02/23/467745559/where-did-all-that-jebbush-superpac-money-go [https://perma.cc/LNB4-LBWS] (noting that the official campaign committee for presidential candidate Jeb Bush "essentially outsourced its media operation to the supposedly independent superPAC”).

151. Citizens United v. FEC, 558 U.S. 310, 357 (2010).

152. Id.

153. 134 S. Ct. 1434 (2014).

154. Id. at 1454 (quoting Citizens United, 558 U.S. at 357). 
contribution can yield.155 If Congress may prohibit the campaign contribution (as it may and has), it should be allowed to prohibit the super PAC contribution as well. If Buckley still stands (and Citizens United says it does), SpeechNow was wrongly decided. Contributions to super PACs cannot reasonably be distinguished from the contributions to candidates whose limitation Buckley upheld.

\section{E. Why Contributions and Expenditures Are Not Fungible: The False Allure of the Hydraulic Hypothesis}

One might suppose that, if wealthy people could not contribute unlimited sums to super PACs, they would use the same funds to make independent expenditures. They would substitute fully protected "speech" for "speech by proxy.” But they probably wouldn't.

Some skeptics have embraced what one might call the hydraulic hypothesis. As the Supreme Court itself once declared, "Money, like water, will always find an outlet."156 The proponents of this hypothesis, however, have offered little evidence to support it.157 If it were true, SpeechNow could not have changed the world. Before SpeechNow, the people who now make multimillion dollar contributions to super PACs would have made multimillion dollar independent expenditures instead. Even expenditures approaching \$1 million by people other than candidates, however, seem to

155. See Edward B. Foley, The "Major Purpose" Test: Distinguishing Between ElectionFocused and Issue-Focused Groups, 31 N. Ky. L. REv. 341, 346 (2004) ("[W] hen a political committee is focused on electing one particular candidate[,] . . a large-dollar gift to that political committee is almost as good as a large-dollar gift to the candidate's own campaign would be as a means to secure improper favoritism from that candidate once in office.”).

156. McConnell v. FEC, 540 U.S. 93, 224 (2003), overruled in part by Citizens United, 558 U.S. 310; see FEC v. Nat'l Conservative Pol. Action Comm., 470 U.S. 480, 519 (1985) (Marshall, J., dissenting) (confessing that Justice Marshall erred in Buckley when he endorsed the distinction between contributions and expenditures because, in his view, when the ability to make direct contributions is limited, people "will find other ways to financially benefit the candidate's campaign”); Samuel Issacharoff \& Pamela S. Karlan, The Hydraulics of Campaign Finance Reform, 77 TEx. L. REV. 1705, 1708 (1999) (“[P]olitical money, like water, has to go somewhere. It never really disappears into thin air.”).

157. See Michael J. Malbin \& Thomas L. Gais, The Day After Reform: Sobering CAMPAign FInANCE LESSONS FROM THE AMERICAN STATES 79 (1998) (“Most [interest groups] have shown little interest in getting around contribution limits.”). Although most interest groups may not take advantage of loopholes and workarounds, Malbin and Gais show that many groups do. Loopholes and workarounds matter, and we do not propose ignoring them. We question only the hypothesis that donors always find a workaround so that contribution limits become futile. We note in addition that large independent expenditures by individuals are an especially unattractive and unlikely workaround. 
have been extremely rare. We know of none at all.158 After SpeechNow, "large contributions by individuals . . . skyrocketed."159

Just as wealthy people apparently did not make large independent political expenditures before SpeechNow, they would be unlikely to make these expenditures if the pre-SpeechNow regime were restored. Spending millions of political dollars effectively requires an organization, one employing people with a variety of skills. If a wealthy person were to establish such an organization as a distinct legal entity, this organization would be called a super PAC. A person who funded this organization would engage in "speech by proxy," and his contribution could be limited.

A wealthy person might employ a personal staff to aid him in making independent expenditures as an individual. He then would face unlimited liability for the torts and breaches of contract committed by staff members in the course of their employment; he would be required to take personal responsibility for the advertisements they placed ("I'm Bobby Billionaire, and I approve this message.”); and one of the dubious things Buckley said about independent expenditures might become true: "Unlike contributions, ... independent expenditures may well provide little assistance to the candidate's campaign and indeed may prove counterproductive.”160 Even if this person could find and employ capable managers, the enterprise would require his personal attention. We suspect that few of the billionaires willing to write large checks to super PACs are willing to manage political organizations themselves.

Contributions to super PACs have advantages over independent expenditures apart from the fact that they save contributors from the need to manage political organizations and take personal responsibility for the messages they send. An early contribution to a super PAC ensures that funds will be available throughout a campaign. A promise to make independent expenditures throughout a campaign is less reliable. The independent spender's promise may not be kept, especially if the benefitted candidacy starts to founder. Moreover, a contributor may feel freer to discuss policy (i.e., what he wants) with a candidate after making a contribution to a super PAC than he would if he were making continuing expenditures on the candidate's behalf. When an irrevocable donation precedes an "ask," the

158. Candidates did sometimes fund their own campaigns, but, as Buckley noted, a candidate who makes expenditures on his own behalf does not corrupt himself. See Buckley v. Valeo, 424 U.S. 1, 53-54 (1976) (per curiam).

Independent expenditures provided one lawful way around contribution limits prior to SpeechNow, and donations to 527, 501(c)(4), and 501(c)(6) groups provided others. See I.R.C. $\S \S 527,501$ (c)(4), 501(c)(6) (2012). Donations to these groups, however, were less effective than direct contributions to candidates both in bringing messages to the public and in buying clout. See Alschuler, supra note 33, at 455-56.

159. Alschuler, supra note 33, at 423.

160. Buckley, 424 U.S. at 47. 
donation is not conditioned on receiving the desired response, and criminal prosecution becomes less likely.161

\section{THE APPEARANCE OF CORRUPTION}

\section{A. Wealth Disparity, Mistrust, and Corruption}

Trust is a social good to be protected .... When it is damaged, the community as a whole suffers; and when it is destroyed, societies falter and collapse.

-Sissela Bok 162

For more than forty years, the Supreme Court has held that Congress may restrict political contributions to prevent corruption and the appearance of corruption. This Part examines the appearance of corruption that unlimited super PAC contributions have produced. The material it presents should be viewed against the background of America's large and growing disparity in the distribution of wealth and the lack of social trust that invariably accompanies a high level of economic inequality.

In 2011, the Nobel Prize-winning economist Joseph Stiglitz published an influential article entitled "Of the $1 \%$, by the $1 \%$, for the $1 \%$." 163 Here's how it began:

It's no use pretending that what has obviously happened has not in fact happened. The upper 1 percent of Americans are now taking in nearly a quarter of the nation's income every year. In terms of wealth rather than income, the top 1 percent control 40 percent. Their lot in life has improved considerably. Twenty-five years ago, the corresponding figures were 12 percent and 33 percent. ... While the top 1 percent have seen their incomes rise 18 percent over the past decade, those in the middle have actually seen their incomes fall. For men with only high-school degrees, the decline has been precipitous-12 percent in the last quarter-century alone. All the growth in recent decades - and more-has gone to those at the top. In terms of income equality, America lags behind [every] country in . . . Europe ....

... [T]he vast inequalities that seemed so troubling in the mid-19th century ... are but a pale shadow of what we are seeing in America today. 164

Some additional data:

161. But see Albert W. Alschuler, Criminal Corruption: Why Broad Definitions of Bribery Make Things Worse, 84 FORDHAM L. REV. 463, 479-82 (2015) (discussing "stream of benefits" or "course of conduct" bribery).

162. Sissela BoK, Lying: Moral Choice in Public and Private Life 26-27 (1978).

163. Joseph E. Stiglitz, Of the 1\%, by the 1\%, for the 1\%, VANITY FAIR (May 2011), http://www.vanityfair.com/news/2011/05/top-one-percent-201105 [https://perma.cc/GH779FWS].

164. Id. Stiglitz's article observed that popular protests were occurring throughout the world in places where a small fraction of the population controlled most of the wealth and where corruption had become a way of life. He wrote, "As we gaze out at the popular fervor in the streets, one question to ask ourselves is this: When will it come to America?" Id. 
- Although the richest 1 percent of Americans in 2013 received about 20 percent of all income (slightly more than the top 1 percent did in the era of Rockefeller and Carnegie), they received only around 10 percent in the decades from 1950 to 1980.165 A "great compression" occurred mostly during World War II, and it produced a "middle class society" that endured for three decades. 166 Among the possible causes of increased inequality since then have been less progressive taxation; less powerful labor unions; an increased number of women entering the workforce at low wages; a minimum wage that lagged behind inflation; the export of manufacturing jobs; automation; greater direct and regulatory subsidization of manufacturing, banking, and insurance; greater protection of software and pharmaceutical patents; greater protection of entertainment-industry copyrights; and protective land-use policies and licensing requirements. In recent decades, shareholders, top managers, financial service providers, elite lawyers, and some health-care providers have captured nearly all gains from increased productivity and trade. 167 In 2016, inequality in the distribution of both wealth

165. See Emmanuel Saez, Striking It Richer: The Evolution of Top Incomes in the UNITED STATES fig.2 (2015), https://eml.berkeley.edu/ saez/saez-UStopincomes-2013.pdf [https://perma.cc/7G4Y-YWSE].

Thomas Piketty, Emmanuel Saez, and Gabriel Zucman report:

The average pre-tax income of the bottom $50 \%$ of adults since 1980 has stagnated at about \$16,000 per adult (in constant 2014 dollars, using the national income deflator) .... As a result, the bottom 50\% income share has collapsed from about $20 \%$ in 1980 to $12 \%$ in 2014 . In the meantime, the average pre-tax income of top $1 \%$ adults rose from $\$ 420,000$ to about $\$ 1.3$ million, and their income share increased from about $12 \%$ in the early 1980 s to $20 \%$ in 2014 . . . In 1980 , top $1 \%$ adults earned on average 27 times more than bottom $50 \%$ adults before tax, while today they earn 81 times more.

... [G]overnment redistribution has offset only a small fraction of the increase in pre-tax inequality.

Thomas Piketty et al., Distributional National Accounts: Methods and Estimates for the United States 2-3 (Nat'l Bureau of Econ. Research, Working Paper No. 22945, 2016), https://eml.berkeley.edu/ saez/Piketty-Saez-ZucmanNBER16.pdf [https://perma.cc/NZ9EWR5J].

166. See generally Claudia Goldin \& Robert A. Margo, The Great Compression: The Wage Structure in the United States at Mid-Century, 107 Q.J. Econ. 1 (1992) (discussing the rapid compression in the wage structure during the 1940's and its maintenance during the subsequent decade and more).

167. See Jonathan Rothwell, Myths of the 1 Percent: What Puts People at the Top, N.Y. TiMES (Nov. 17, 2017), https://www.nytimes.com/2017/11/17/upshot/income-inequalityunited-states.html [https://perma.cc/MWW2-MCDH]; Causes of Income Inequality, SEvEN PILLARS INST. (Jan. 22, 2015), https://sevenpillarsinstitute.org/causes-economic-inequality/ [https://perma.cc/XK9S-UKR2]. For further discussion of the causes of increased inequality, see generally DEAN BAKER, RigGed: How Globalization AND the Rules OF THE MODERN ECONOMY WERE STRUCTURED TO MAKE THE Rich Richer (2016); BRINK LiNDSEy \& STEVEN M. Teles, The Captured Economy: How the POWERful EnRICH TheMSElves, SlOW DOWN GROWTH, AND INCREASE INEQUALITY (2017); RICHARD V. REEVES, DREAM HOARDERS: How THE AMERICAN UpPER MidDle Class Is LEAVING EVERYONE ElSE IN THE Dust, Why That Is a Problem, And What to Do About It (2017). 
and income was greater than it had been at any point in a study period encompassing the previous fifty-four years. 168

- In 2011, the net worth of America's wealthiest 400 individuals exceeded the net worth of half of all American households. 169

- The six heirs of Wal-Mart's founder have as much wealth as the bottom 41.5 percent of all Americans. 170

- Fifty years ago, the average compensation of the CEOs of the largest U.S. firms was twenty times greater than that of the average U.S. worker. It is 200 or 300 times greater today. 171

- The United States is "the most unequal rich country on earth" not only because its rich are especially rich but also because, among developed countries, its poor are especially poor. ${ }^{172}$

168. Edward N. Wolff, Household Wealth Trends in the United States, 1962-2016: Has Middle Class Wealth Recovered? 36 (Nat'l Bureau of Econ. Research, Working Paper No. 24085, 2017), http://papers.nber.org/tmp/7707-w24085.pdf [https://perma.cc/GNA9-G4TA]. A Washington Post columnist noted that "the top 1 percent of households own more wealth than the bottom 90 percent combined" and that the top 1 percent's share of total American wealth (40 percent) is twice the top 1 percent's share in France, the United Kingdom, or Canada. Christopher Ingraham, The Richest 1 Percent Now Owns More of the Country's Wealth than at Any Time in the Past 50 Years, WAsh. Post (Dec. 6, 2017), https://www.washingtonpost.com/news/wonk/wp/2017/12/06/the-richest-1-percent-nowowns-more-of-the-countrys-wealth-than-at-any-time-in-the-past-50-years [https://perma.cc/ 9AH3-FEBA].

169. Politifact Wisconsin reviewed the relevant sources and spoke with several respected economists after filmmaker Michael Moore made this claim in 2011, and it rated the claim True. For its review of the sources, see Tom Kertscher, Michael Moore Says 400 Americans Have More Wealth than Half of All Americans Combined, PoliTifact WIS. (Mar. 10, 2011, 4:16 PM), http://www.politifact.com/wisconsin/statements/2011/mar/10/michaelmoore/michael-moore-says-400-americans-have-more-wealth- $\quad$ [https://perma.cc/HE7GGBT9]. A 2017 report makes an even more striking claim: "The three wealthiest people in the United States-Bill Gates, Jeff Bezos, and Warren Buffett-now own more wealth than the entire bottom half of the American population combined.” CHUCK COLLINS \& Josh HoxiE, InST. FOR POL'y STUDIES, BILliONAIRE BONANZA: THE FORBES 400 AND THE REST OF Us 2 (2017), http://www.ips-dc.org/wp-content/uploads/2017/11/BILLIONAIRE-BONANZA2017-FinalV.pdf [https://perma.cc/WBH6-H7FJ].

170. Again, Politifact Wisconsin did impressive research after an advocacy group made this claim, and it rated the claim True. Tom Kertscher, Just How Wealthy Is the Wal-Mart Walton Family?, POLiTIFAct Wis. (Dec. 8, 2013, 5:00 AM), http://www.politifact.com/wisconsin/ statements/2013/dec/08/one-wisconsin-now/just-how-wealthy-wal-mart-walton-family/ [https://perma.cc/KV4S-3DHF].

171. Lawrence Mishel \& Alyssa Davis, Top CEOs Make 300 Times More than Typical Workers, ECON. POL'y INST. (June 21, 2015), http://www.epi.org/publication/top-ceos-make300-times-more-than-workers-pay-growth-surpasses-market-gains-and-the-rest-of-the-0-1percent/ [https://perma.cc/7ZXE-2HLA]; see Executive Paywatch, AFL-CIO, https://aflcio.org/paywatch [https://perma.cc/H47M-VN5C] (last visited Mar. 15, 2018) (reporting that in 2016 the average compensation of the CEOs of S\&P 500 Index companies was 347 times greater than the compensation of the average American worker). Although the 300-to- 1 figure is the one most commonly cited, some maintain that the ratio of CEO-toworker compensation at the largest firms is as low as 200 to 1. See Glenn Kessler, Clinton's Claim That CEOs Make 300 Times More than American Workers, WASH. Post (Apr. 16, 2015), https://www.washingtonpost.com/news/fact-checker/wp/2015/04/16/clintons-claimthat-ceos-make-300-times-more-than-american-workers/ [https://perma.cc/6UZU-B6ER].

172. Jonathan Fisher \& Timothy M. Smeeding, Income Inequality, PATHWAYS, Special Issue 2016, at 32, 34, 36, http://inequality.stanford.edu/sites/default/files/Pathways-SOTU2016.pdf [https://perma.cc/HTB6-HDYB]. The poorest 10 percent of the U.S. population has 
Social trust is strongly correlated with equality in the distribution of wealth. This trust is typically measured by responses to the survey question, "Generally speaking, would you say most people can be trusted or that you can't be too careful in dealing with people?" 173 In the nations in which social trust is highest, more than 60 percent of respondents say that most people can be trusted. These nations are the most equal in the distribution of wealthplaces like Norway, Sweden, and Finland. In the nations in which social trust is lowest, fewer than 10 percent say that most people can be trusted. These nations are among the least equal-places like Colombia, Brazil, Ecuador, and Peru. ${ }^{174}$ Studies employing multivariate analysis in various settings confirm what the raw figures suggest - that economic inequality is a strong predictor of mistrust. 175

Studies of changing attitudes over time show the same pattern as studies of geographical variation. As wealth disparities increased in America, the proportion of Americans who believe that most people can be trusted fellfrom 46 percent in 1972 through 1974 to 33 percent in 2010 through 2012.176 Trust levels are positively correlated with wealth as well as with equality, but the United States now departs from the pattern. Although the United States ranks high among developed nations in median household income, it ranks low among these nations in social trust. 177

Trust is a major component of what economists, sociologists, and political scientists call social capital. The political scientist Eric Uslander explains:

Trust is the chicken soup of social life. It reputedly brings us all sorts of good things - from a willingness to get involved in our communities to higher rates of economic growth, to satisfaction with government performance, to making daily life more pleasant.... An active and engaged

more real income per capita than the poorest 10 percent in Italy, but it has less per capita income than the poorest 10 percent in Norway, Sweden, France, Germany, Ireland, the United Kingdom, and Australia. Id. at 34.

173. See, e.g., Pew Research Ctr., Americans and Social Trust: Who, Where and WHY 1 (2007), http://www.pewsocialtrends.org/files/2010/10/SocialTrust.pdf [https://perma.cc/2XME-E4XZ].

174. See Esteban Ortiz-Ospina \& Max Roser, Trust, OuR World DATA, https://ourworldindata.org/trust [https://perma.cc/4HDT-EBRH] (last visited Mar. 15, 2018) (describing levels of trust); Richard Wilkinson, How Economic Inequality Harms Societies, TED (July 2011), https://www.ted.com/talks/richard_wilkinson/transcript [https://perma.cc/VH6S-8ZC4] (describing the correlation between trust and levels of economic equality).

175. See Bo Rothstein \& Eric M. Uslaner, All for All: Equality, Corruption, and Social Trust, 58 World Pol. 41, 48 (2005); Henrik Jordahl, Inequality and Trust 17 (Research Inst. of Indus. Econ., Working Paper No. 715, 2007), http://www.ifn.se/wfiles/wp/wp715.pdf [https://perma.cc/6RPA-65CX] (reviewing the empirical literature and declaring that the "relationship shows up consistently in different studies, although in a few of them it is not statistically significant”).

176. Jean M. Twenge et al., Declines in Trust in Others and Confidence in Institutions Among American Adults and Late Adolescents, 1972-2012, 25 PsYch. SCI. 1914, 1918 (2014).

177. Lila Shapiro, Money and Trust: Richer, More Equal Countries Are More Trusting, Study Finds, HuFfington PosT (Apr. 21, 2011, 4:33 PM), http://www.huffingtonpost.com/ 2011/04/20/trust-wealth_n_851519.html [https://perma.cc/MX4Q-EB5S]. 
citizenry is motivated by a shared sense of common purpose that ultimately helps people find compromises to difficult issues. 178

Resentment of "the 1 percent" by a significant part of "the 99 percent" may rest partly on jealousy of their mansions, but our guess is that it stems much more from the perception that "the 1 percent" have bought government favors and made government less democratic. The $\$ 2.7$ million electric train set in Robert Mercer's basement probably troubles people less than the perception that "Mercer has surrounded [President Trump] with his people, and his people have an outsized influence over the running of our country, simply because Robert Mercer paid for their seats."179

As trust in other people has declined, trust in government has too. The percentage of Americans who believed they could trust the federal government most of the time was 77 percent in 1964. It is 19 percent today. ${ }^{180}$ In 1964, only 29 percent of respondents said that the government was "pretty much run by a few big interests looking out for themselves." 181 Now more than three-quarters take that view.182 A University of Maryland survey conducted during the 2016 presidential campaign reported in fact that 92 percent of registered voters (96 percent of Trump supporters and 87 percent of Clinton supporters) believed that the government was "pretty much run by a few big interests looking out for themselves.” This figure had increased from 81 percent only six years earlier. ${ }^{183}$ The perceived capture of government by a wealthy minority contributes to the belief that the system of economic distribution is unfair. Middle-income Americans may bristle at revelations that many of the superrich pay taxes at a lower rate than they do184 and that the federal program for providing medical care to seniors is prohibited by law from seeking lower drug prices. 185

178. Eric M. Uslaner, Producing and Consuming Trust, 115 POL. SCI. Q. 569, 569 (2000).

179. Magerman, supra note 68 (op-ed by an executive of Robert Mercer's hedge fund); see Jane Mayer, The Reclusive Hedge-Fund Tycoon Behind the Trump Presidency: How Robert Mercer Exploited America's Populist Insurgency, NeW YORKER (Mar. 27, 2017), http://www.newyorker.com/magazine/2017/03/27/the-reclusive-hedge-fund-tycoon-behindthe-trump-presidency [https://perma.cc/B75B-85A9].

180. PEW RESEARCh CTR., supra note 12, at 18.

181. Id. at 26 .

182. Id. at 35 .

183. Voice of the People, Voter Anger with Government ANd the 2016 Election 5 (2016), http://vop.org/wp-content/uploads/2016/11/Dissatisfaction_Report.pdf [https://perma.cc/YLJ3-JGFG].

184. See, e.g., Warren E. Buffett, Stop Coddling the Super-Rich, N.Y. TIMES (Aug. 14, 2011), http://www.nytimes.com/2011/08/15/opinion/stop-coddling-the-super-rich.html [https://perma.cc/ER7D-3PDP] (“[W] hat I paid was only 17.4 percent of my taxable incomeand that's actually a lower percentage than was paid by any of the other 20 people in our office.... My friends and I have been coddled long enough by a billionaire-friendly Congress.”).

185. See Theodore T. Lee et al., The Politics of Medicare and Drug-Price Negotiation (Updated), HEALTH AfF. BLOG (Sept. 19, 2016), http://healthaffairs.org/blog/2016/09/19/thepolitics-of-medicare-and-drug-price-negotiation/ [https://perma.cc/D3GV-GRHC]. 
Government corruption-broadly defined as the capture of government by special interests186 - seems to make everyone angry, from the Tea Party through the Occupy movement. Other than opposition to terrorism, corruption may be the only issue that unites all of America.187

A 2012 Gallup survey found that 87 percent of Americans regard "reducing corruption in the federal government" as either extremely important or very important, placing this goal slightly behind "creating good jobs" but ahead of dealing with terrorism and other international threats, reducing the federal budget deficit, ensuring the long-term stability of Social Security and Medicare, improving the nation's public schools, making health care available and affordable, overcoming political gridlock, making college education available and affordable, and dealing with environmental concerns such as global warming. 188 A 2015 Gallup survey reported that 75 percent of Americans view government corruption as "widespread," an increase from 67 percent in 2007.189

Empirical studies validate the belief that our government responds more to the agendas of wealthy elites than to the desires of the majority. Martin Gilens and Benjamin Page write:

In the United States, our findings indicate, the majority does not rule-at least not in the causal sense of actually determining policy outcomes. When a majority of citizens disagrees with economic elites or with organized interests, they generally lose .... [E]ven when fairly large majorities of Americans favor policy change, they generally do not get it. 190

186. See ARISTOTLE's Politics 114 (Benjamin Jowett trans., 1920) ("The true forms of government ... . are those in which the one, or the few, or the many, govern with a view to the common interest; but governments which rule with a view to the private interest... are perversions.").

187. Cf. Thomas Piketty, Capital in the Twenty-First Century 1 (2014) ("When the rate of return on capital exceeds the rate of growth of output and income, ... capitalism automatically generates arbitrary and unsustainable inequalities that radically undermine the meritocratic values on which democratic societies are based.”); GANESH SITARAMAN, THE CRISIS OF THE MIDDLE-Class CONSTITUTION: Why ECONOMIC INEQUALITY THREATENS OUR REPUBLIC 5 (2017) (declaring that "the basic foundation upon which our middle-class constitution was built-the prerequisite of relative economic equality-is crumbling” and asking whether "our constitutional system [can] survive the collapse of the middle class").

188. Jeffrey M. Jones, Americans Want Next President to Prioritize Jobs, Corruption, GALLuP (July 30, 2012), http://www.gallup.com/poll/156347/Americans-Next-PresidentPrioritize-Jobs-Corruption.aspx [https://perma.cc/FDT8-5ECX].

189. 75\% in U.S. See Widespread Government Corruption, Gallup (Sept. 19, 2015), http://www.gallup.com/poll/185759/widespread-government-corruption.aspx

[https://perma.cc/XDJ4-JEPV]. A Chapman University survey in 2015 found that more Americans were afraid or very afraid of government corruption than were afraid of terrorist attacks, cyber terrorism, bio-warfare, or economic collapse. Sheri Ledbetter, What Americans Fear Most-Chapman University's Second Annual Survey of American Fears Released, CHAPMAN U. PRESS RoOM (Oct. 13, 2015), https://blogs.chapman.edu/press-room/2015/ 10/13/what-americans-fear-most-chapman-universitys-second-annual-survey-of-americanfears-released/ [https://perma.cc/AX57-RWWW].

190. Martin Gilens \& Benjamin I. Page, Testing Theories of American Politics: Elites, Interest Groups, and Average Citizens, 12 PeRsPECTIVEs ON POL. 564, 576 (2014); see also Martin Gilens \& Benjamin I. Page, Critics Argued with Our Analysis of U.S. Political 
Many other studies have made similar findings.191

Before Congress approved the Tax Cut and Jobs Act of 2017, Representative Chris Collins told the press, "My donors are basically saying, 'Get it done or don't ever call me again.'”192 A review of opinion polls calls the Tax Cut and Jobs Act "the most unpopular major piece of legislation to pass in decades.”193

\section{B. Defining Corruption and the Appearance of Corruption}

Citizens United took a narrow view of corruption. The Supreme Court declared, "When Buckley identified a sufficiently important governmental interest in preventing corruption or the appearance of corruption, that interest was limited to quid pro quo corruption." 194 The Court said that "[i]ngratiation and access . . . are not corruption,"195 and "[t]he fact that speakers may have influence over or access to elected officials does not mean that these officials are corrupt."196 In fact, "[t]he practices Buckley noted would be covered by bribery laws if a quid pro quo arrangement were proved."197

Four Supreme Court Justices have called these statements dicta,198 and if the holding of Citizens United is that "the Government cannot restrict political speech based on the speaker's corporate identity,"199 these Justices were correct. None of the Court's statements concerning cognizable corruption advanced the Court's holding in any way.

Nevertheless, in the discussion that follows, this Article accepts all of the Court's dicta but one. When we say that super PAC contributions create the appearance of corruption, we mean quid pro quo corruption, and we do not

Inequality. Here Are 5 Ways They're Wrong, WASH. Post (May 23, 2016), http://wapo.st/1TDPnzE?tid=ss_tw\&utm_term=.e8d5b00edfe8 [https://perma.cc/5CRDT7D5].

191. See, e.g., Larry M. Bartels, Unequal Democracy: The Political Economy of THE NEW GILDED AGE (2008) (discussing the political causes and consequences of America's growing income gap). See generally MARTIN GILENS, AFFLUENCE AND INFLUENCE: ECONOMIC IneQuality AND Political Power in AMERICA (2012); JACOB S. HACKer \& PAUl Pierson, Winner-TAKe-All Politics: How WASHINGTON MADE THE Rich RicheR-AND TURNED ITS

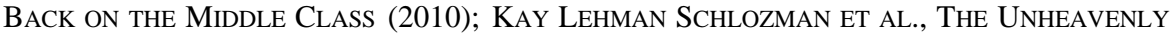
Chorus: Unequal Political Voice and the Broken Promise of American Democracy (2012); Lawrence R. Jacobs \& Benjamin Page, Who Influences Foreign Policy?, 99 AM. PoL. SCI. REV. 107 (2005); Elizabeth Rigby \& Gerald C. Wright, Political Parties and Representation of the Poor in American States, 57 AM. J. PoL. SCI. 552 (2013).

192. Cristina Marcos, GOP Lawmaker: Donors Are Pushing Me to Get Tax Reform Done, HiLl (Nov. 7, 2017), http://thehill.com/homenews/house/359110-gop-lawmaker-donors-arepushing-me-to-get-tax-reform-done [https://perma.cc/ETZ4-JP8X].

193. Susan Milligan, Ignoring the Will of the People, U.S. NEws (Dec. 22, 2017, 6:00 AM), https://www.usnews.com/news/the-report/articles/2017-12-22/why-the-wildly-unpopulartax-bill-passed [https://perma.cc/6QTV-WMJ3].

194. Citizens United v. FEC, 558 U.S. 310, 359 (2010).

195. Id. at 360 .

196. Id. at 359.

197. Id. at 356 (citation omitted).

198. McCutcheon v. FEC, 134 S. Ct. 1434, 1471 (2014) (Breyer, J., joined by Ginsburg, Sotomayor \& Kagan, JJ., dissenting).

199. Citizens United, 558 U.S. at 346. 
include ingratiation and access. We balk, however, at Citizens United's indication that Congress may limit political contributions and expenditures only to prevent criminal bribery or the appearance of this bribery.

Like several other broad declarations in the Citizens United opinion,200 the Court's declaration that "[t]he practices Buckley noted would be covered by bribery laws if a quid pro quo arrangement [was] proved" was probably not meant literally.201 Justice Kennedy might not have had the definition of criminal bribery precisely in mind when he wrote those words, and he might not have meant to bind Congress's regulatory power tightly to this narrow, contestable definition of a crime. In McCormick v. United States, 202 the Supreme Court held that campaign contributions may be treated as bribes only when "the payments are made in return for an explicit promise or undertaking by the official to perform or not to perform an official act.”203

In fact, Justice Kennedy himself criticized the Court's requirement of an "explicit” quid pro quo one year after McCormick. He wrote in a concurring opinion that a public official and his benefactor "need not state the quid pro quo in express terms, for otherwise the law's effect could be frustrated by knowing winks and nods."204 It seems unlikely that Citizens United meant to exclude from the category of quid pro quo corruption conduct that Justice Kennedy would treat as felonious.

Moreover, Citizens United purported to follow Buckley, which spoke not of bribes but of "undue influence,"205 "improper influence,"206 and "postelection special favors."207 Buckley in fact rejected the argument that "contribution limitations must be invalidated because bribery laws and narrowly drawn disclosure requirements constitute a less restrictive means of dealing with 'proven and suspected quid pro quo arrangements."'208 The Court explained, "[L]aws making criminal the giving and taking of bribes deal with only the most blatant and specific attempts of those with money to influence government action.”209 Buckley upheld contribution limits not

200. See supra Part I.C.

201. Citizens United, 558 U.S. at 356 (citation omitted).

202. 500 U.S. 257 (1991).

203. Id. at 273. Although the Eleventh Circuit has concluded that a later Supreme Court decision modified McCormick, see United States v. Siegelman, 640 F.3d 1159, 1171 (11th Cir. 2011) (discussing Evans v. United States, 504 U.S. 255 (1992)), at least seven other courts of appeals insist that an explicit agreement remains necessary, see United States v. Ring, 706 F.3d 460, 465-66 (D.C. Cir. 2013); United States v. Turner, 684 F.3d 244, 253-54, 258 (1st Cir. 2012); United States v. Kincaid-Chauncey, 556 F.3d 923, 936-37 (9th Cir. 2009); United States v. Abbey, 560 F.3d 513, 515-19 (6th Cir. 2009); United States v. Ganim, 510 F.3d 134, 142-43 (2d Cir. 2007); United States v. Antico, 275 F.3d 245, 256-61 (3d Cir. 2001); United States v. Giles, 246 F.3d 966, 971-72 (7th Cir. 2001).

204. Evans, 504 U.S. at 274 (Kennedy, J., concurring). For a defense of McCormick's “explicit” quid pro quo requirement, see Alschuler, supra note 161, at 482-84.

205. Buckley v. Valeo, 424 U.S. 1, 53, 70, 76 (1976) (per curiam).

206. Id. at $29,30,45,58,96$.

207. Id. at 67. Taken literally, the Court's statement that "[t]he practices Buckley noted would be covered by bribery laws if a quid pro quo arrangement were proved" was an assertion of fact, and the assertion was false.

208. Buckley, 424 U.S. at 27.

209. Id. at 27-28. 
because they prevented bribery "arrangements" that might be difficult to prove but because they blocked influences less "blatant and specific" than bribes. The Court in fact pointed to several "deeply disturbing examples" of what it called quid pro quo corruption, and none of them involved bribery.210

Post-Buckley decisions were equally clear. The Court wrote in 2000 that its concern was "not confined to bribery of public officials, but extend[ed] to the broader threat from politicians too compliant with the wishes of large contributors." 211 A year later it declared that corruption must be "understood not only as quid pro quo agreements, but also as undue influence on an officeholder's judgment."212 Three years later, the Court wrote, "Congress' legitimate interest extends beyond preventing simple cash-for-votes corruption to curbing 'undue influence."”213 The Court added that it was "not only plausible, but likely, that candidates would feel grateful for ... donations and that donors would seek to exploit that gratitude.”214 An unexplained onesentence dictum should not cast into the void all of the Court's prior descriptions of cognizable corruption.

In fact, a post-Citizens United opinion joined by Justice Kennedy and three other members of the Citizens United majority made clear that cognizable corruption is broader than the "nothing but bribery" dictum suggests. Chief Justice Roberts's plurality opinion in McCutcheon v. FEC gave this explanation of why Buckley upheld contribution limits: "The propriety of large contributions to individual candidates turned on the subjective intent of

210. Id. at 26-27. Immediately after noting that the integrity of "our system of representative democracy" can be undermined by large contributions "given to secure a political quid pro quo," the Court wrote, "Although the scope of such pernicious practices can never be reliably ascertained, the deeply disturbing examples surfacing after the 1972 election demonstrate that the problem is not an illusory one.” Id. It then cited the D.C. Circuit's recitation of these examples in its own Buckley v. Valeo opinion. Id. at 27 n.28 (citing Buckley v. Valeo, 519 F.2d 821, 839-40 nn.36-38 (D.C. Cir. 1975) (per curiam)). One of the illustrations to which the Supreme Court referred was "the revelation [of] the extensive contributions by dairy organizations to Nixon fundraisers, in order to gain a meeting with White House officials on price supports.” Buckley, 519 F.2d at 839 n.36. Another was "lavish contributions by groups or individuals with special interests to legislators from both parties, e.g., ... by H. Ross Perot, whose company supplies data processing for Medicare and Medicaid programs, to members of the House Ways and Means and Senate Finance Committees.” Id. at 839 n.37. The third was the appointment of campaign contributors as ambassadors, a practice whose "scale and volume" revealed a "widespread understanding that such contributions were a means of obtaining the recognition needed to be actively considered.” Id. at 840 n.38. The Buckley Court had no doubt of Congress's power to limit these "pernicious" and "deeply disturbing" practices, none of which involved bribery.

211. Nixon v. Shrink Mo. Gov’t PAC, 528 U.S. 377, 389 (2000).

212. Colo. Republican Fed. Campaign Comm. v. FEC (Colorado II), 533 U.S. 431, 441 (2001) (citing Nixon, 528 U.S. at 388).

213. McConnell v. FEC, 540 U.S. 93, 150 (2003) (quoting Colo. Republican Fed. Campaign Comm. v. FEC (Colorado II), 533 U.S. 431, 438 (2001)), overruled in part by Citizens United v. FEC, 558 U.S. 310 (2010); see also FEC v. Nat'l Conservative Pol. Action Comm., 470 U.S. 480, 497 (1985) ("Corruption is a subversion of the political process. Elected officials are influenced to act contrary to their obligations of office by the prospect of financial gain to themselves or infusions of money into their campaigns.”).

214. McConnell, 540 U.S. at 145. 
donors, and the Court concluded that there was no way to tell which donors sought improper influence over legislators' actions.”215

It would be difficult to improve on this description of Buckley's rationale. According to the McCutcheon plurality, seeking improper influence justifies restricting campaign contributions. Moreover, because there is no practical way to determine when this corrupt intent exists, Congress may prohibit contributions large enough to pose a significant risk of this improper motivation.

If, as the McCutcheon plurality recognized, deliberately seeking improper influence is corrupt, so is deliberately providing it. Favoritism for donors is not itself bribery. Every definition of criminal bribery requires either a corrupt understanding or a corrupt mental state at the time a benefit is received. None includes subsequent favoritism for a benefactor.216 But even when a payoff of government benefits has not been arranged in advance, this payoff is corrupt. Using public dollars to repay private favors is what Buckley meant when it spoke of quid pro quo corruption. Both before and after Citizens United, the Supreme Court has treated this corruption as sufficient to justify contribution limits. Despite Citizens United's confusing dictum, we adhere in the discussion that follows to the Court's long-standing view.217

Buckley said that Congress may limit political contributions to prevent not only corruption but also the appearance of corruption.218 Although "appearance" has a myriad of meanings,219 the Court has left the term undefined for more than forty years.

We think this term should be understood narrowly. The "appearance of corruption" is not "anything that smells a bit like corruption." It is instead "something that is believed or suspected to be corruption." Of course the suspected corruption must be of the kind that justifies regulation.

Moreover, an unreasonable belief in the existence of corruption cannot justify limiting speech. The appropriate remedy for an unreasonable belief is not limiting speech but "more speech." 220 Thus the "appearance of corruption" should be understood to mean something that is reasonably

215. McCutcheon v. FEC, 134 S. Ct. 1434, 1447 (2014).

216. See Alschuler, supra note 161, at 481.

217. There are good reasons for not punishing deliberate favoritism as a crime. If an official were subject to imprisonment whenever a jury could be persuaded that he acted deliberately to benefit someone who once did a favor for him, only a fool would take the job. The law of bribery accordingly requires a stronger inference-an inference that, at the time an official accepted a benefit, he agreed at least implicitly to provide some governmental action in return. Seeking to reduce deliberate favoritism through campaign finance law and other specific ex ante regulation, however, does not threaten imprisonment on the basis of ex post inferences of improper intent. There is no good reason for not including this favoritism among the kinds of corruption that can justify ex ante regulation. See McConnell, 540 U.S. at 153 ("[U]nlike straight cash-for-votes transactions, [favoritism for those who have made large financial contributions] is neither easily detected nor practical to criminalize. The best means of prevention is to identify and to remove the temptation."), overruled in part by Citizens United, 558 U.S. 310.

218. E.g., Buckley v. Valeo, 424 U.S. 1, 27 (1976) (per curiam).

219. See Adam M. Samaha, Regulation for the Sake of Appearance, 125 HARV. L. REv. 1563, 1573 (2012).

220. See Whitney v. California, 274 U.S. 357, 377 (1927) (Brandeis, J., concurring). 
believed or suspected to be corruption or something that might in fact be corruption of the sort that justifies regulation.

Of course, as the McCutcheon plurality recognized, motives are often mixed and rarely revealed, and inferences about particular situations and particular actors are likely to be speculative and fallible. These inferences may reflect an observer's trust or cynicism as much as or more than they reflect the actual motivations of public officials.

Consider an exchange that occurred at the Senate hearing on the confirmation of Betsy DeVos to be Secretary of Education. When Senator Bernie Sanders asked the nominee how much her family had contributed to the Republican Party over the years, she replied that she did not know.221 She conceded, however, that $\$ 200$ million was "in the ballpark." Sanders then asked, "Do you think, if you were not a multi-billionaire, if your family had not made hundreds of millions of dollars of contributions to the Republican Party, that you would be sitting here today?” DeVos replied, "Senator, as a matter of fact, I do think that there would be that possibility. I've worked very hard on behalf of parents and children for the last almost 30 years ...."222

In the absence of DeVos's family's contributions, her nomination might have been "possible" just as she said, but she could no more deny that these contributions had prompted her nomination than Sanders could show that they had done so. When the actions of elected officials benefit their supporters (as of course they usually do), these actions may reflect policy or principle rather than corruption. Even when officials give corrupt payoffs to benefactors, however, they can almost always offer colorable public explanations.

Although judgments about particular situations and particular actors are often problematic, global assessments-or judgments of statistical likelihood-can be easy. When favor seekers make multi-million-dollar contributions to super PACs, one needs no more than a rudimentary understanding of human nature to expect more than occasional corruption. When elected officials then appear to advance the interests of wealthy donors rather than the public, 223 the intuition seems confirmed. In explaining why the appearance of corruption can justify limiting contributions, Buckley noted the importance of the public's perception of government generally: "Congress could legitimately conclude that the avoidance of the appearance of improper influence 'is also critical . . . if confidence in the system of representative Government is not to be eroded to a disastrous extent."'224

221. Valerie Strauss, Sanders to DeVos: Would You Be Trump's Education Nominee If You Weren't a Billionaire?, WASH. Post (Jan. 18, 2017), https://www.washingtonpost.com/ news/answer-sheet/wp/2017/01/18/sanders-to-devos-would-you-be-trumps-educationnominee-if-you-werent-a-billionaire/?utm_term=.2e27e4b78907] [https://perma.cc/EF889HC4].

222. Id.

223. See supra notes 190-93 and accompanying text.

224. Buckley v. Valeo, 424 U.S. 1, 27 (1976) (per curiam) (quoting U.S. Civil Serv. Comm’n v. Nat'l Ass'n of Letter Carriers, 413 U.S. 548, 565 (1973)). 
Although Buckley upheld Congress's power to limit political contributions, SpeechNow effectively abrogated it. Since then, Buckley's dark prophecy appears to have been fulfilled. Confidence in the system of representative government has been "eroded to a disastrous extent." The following Parts of this Article provide some evidence.

\section{The Presidential Campaign of 2016}

In the Democratic presidential primaries of 2016, Senator Bernie Sanders received more than twelve million votes, 43 percent of the total. 225 Sanders's refusal to accept any support from super PACs was a prominent feature of his campaign. By the campaign's end, audiences were chanting with him the amount of the average contribution he received-\$27.226 He asked his principal primary opponent, "Are you qualified to be President of the United States when you're raising millions of dollars from Wall Street whose greed, recklessness and illegal behavior helped to destroy our economy?"227

When Sanders announced his candidacy, he offered this view of the corruption produced by unlimited political contributions: "[T]he American political system has been totally corrupted, and the foundations of American democracy are being undermined. What the Supreme Court essentially said was that it was not good enough for the billionaire class to own much of our economy. They could now own the U.S. government as well."228 Sanders added, "We now have a political situation where billionaires are literally able to buy elections and candidates. Let's not kid ourselves: That is the reality right now.”229

The nominee of the Democratic Party for President was former Senator and Secretary of State Hillary Clinton. The principal super PAC supporting her candidacy, Priorities USA Action, received donations of \$1 million or more from seventy-seven individuals - and donations of $\$ 200$ or more from 759 individuals. ${ }^{230}$ Clinton nevertheless sharply criticized America’s system

\footnotetext{
225. 2016 Democratic Popular Vote, REALCLEARPolitics, https://www.realclearpolitics.com/epolls/2016/president/democratic_vote_count.html [https://perma.cc/Z5UW-DUUN] (last visited Mar. 15, 2018).

226. Scott Bixby et al., Thousands Turn Out for Bernie Sanders Rally Ahead of PrimaryAs It Happened, GuARDIAN (Apr. 13, 2016, 8:43 PM), https://www.theguardian.com/usnews/live/2016/apr/13/us-election-campaign-live-sanders-clinton-trump-cruz-kasich [https://perma.cc/Q9W9-GCHW].

227. Sam Frizell, Clinton and Sanders Clash on Qualifications As Democratic Race Gets Bitter, TiME (Apr. 7, 2016), http://time.com/4284934/bernie-sanders-hillary-clinton-qualifiednew-york-primary/ [https://perma.cc/YPN8-CFAC].

228. Bernie's Announcement, BERNIE (May 26, 2015), https://berniesanders.com/berniesannouncement/ [https://perma.cc/P6KD-KV8W].

229. Paul Kane \& Philip Rucker, An Unlikely Contender, Sanders Takes On "Billionaire Class" in 2016 Bid, WAsH. Post (Apr. 30, 2015), https://www.washingtonpost.com/politics/sanders-takes-on-billionaire-class-in-launching2016-bid-against-clinton/2015/04/30/4849fe32-ef3a-11e4-a55f-38924fca94f9_story.html? utm_term=.54f797ec0db6 [https://perma.cc/F32W-68YA].

230. Priorities USA Action, Contributors 2016 Cycle, OPENSECRETS.ORG, https://www.opensecrets.org/pacs/pacgave2.php?sort=A\&cmte=C00495861\&cycle=2016\&P age $=1$ [https://perma.cc/MP2J-L4EJ] (last visited Mar. 15, 2018); see also Paul Blumenthal, Hillary Clinton's Super PAC Has Raised More Money than Any Super PAC Ever: Nearly All
} 
of campaign finance. She promised to "fight hard to end the stranglehold that the wealthy and special interests have on so much of our government,"231 to "appoint Supreme Court justices who will get money out of politics,"232 and "if necessary [to] pass a constitutional amendment to overturn Citizens United.”233

The Republican Party's nominee, developer Donald Trump, portrayed himself as "the ultimate outsider," 234 determined to "drain the swamp in Washington, D.C.”235 Although Trump later reconsidered,236 he initially pledged,

I will not be controlled by the donors, special interests, and lobbyists who have corrupted our politics and politicians for far too long. I have disavowed all Super PAC's, requested the return of all donations made to said PAC's, and I am calling on all Presidential candidates to do the same. 237

\section{Trump contended:}

[I]t's not just the political system that's rigged. It's the whole economy. It's rigged by big donors who want to keep down wages. It's rigged by big businesses who want to leave our country, fire our workers, and sell their products back into the U.S. with absolutely no consequences for them. It's rigged by bureaucrats who are trapping kids in failing schools. It's rigged against you, the American people.238

In a primary debate, Trump declared, "[T] by the way, folks. Very corrupt. ... There is total control of the candidates, I know it better than anybody that probably ever lived. ... I know it so well because I was on both sides of it.... I've always made large

of the Money Has Come From Seven-Figure Donors, HufFIngton Post (Oct. 27, 2016, 8:24 PM), http://www.huffingtonpost.com/entry/hillary-clinton-super-pac_us_5812833ce4b0990e dc303558 [https://perma.cc/2C5Y-VK23].

231. Hillary Clinton Delivers Address on Economy, CNN (June 22, 2016, 3:02 PM), http://www.cnn.com/TRANSCRIPTS/1606/22/cnr.07.html [https://perma.cc/4SDU-3QNT].

232. Transcript, Hillary Clinton's DNC Speech, Annotated, L.A. TIMES (July 28, 2016), http://www.latimes.com/politics/la-na-pol-hillary-clinton-convention-speech-transcript20160728-snap-htmlstory.html [https://perma.cc/F8HR-9C2B].

233. Id.

234. Trump Calls Himself “Ultimate Outsider” as He Asks for Votes, REUTERS (Nov. 6, 2016, 1:42 PM), https://www.reuters.com/video/2016/11/06/trump-calls-himself-ultimateoutsider-as?videoId=370377889 [https://perma.cc/FQM4-WUV9].

235. Trump's First Hundred Days?, WALL ST. J. (Oct. 23, 2016), https://www.wsj.com/ articles/trumps-first-hundred-days-1477271323 [https://perma.cc/NQB6-9MQL].

236. Dave Leventhal, Donald Trump Embraces Donors, Super PACs He Once Decried, TimE (June 17, 2016), http://time.com/4373124/donald-trump-donors-super-pacs/ [https://perma.cc/8YRY-ARPS].

237. Benjy Sarlin, Donald Trump Says No to Super PACs, Demands Others Do Same, MSNBC (Oct. 23, 2015, 10:58 AM), http://www.msnbc.com/msnbc/donald-trump-says-nosuper-pacs-demands-others-do-same [https://perma.cc/897P-XHNQ].

238. Full Transcript: Donald Trump NYC Speech on Stakes of the Election, PoLITICO (June 22, 2016, 10:50 AM), http://www.politico.com/story/2016/06/transcript-trump-speech-onthe-stakes-of-the-election-224654 [https://perma.cc/ZSR7-VZVV]. Trump also said, "The choice in this election is a choice between taking our government back from the special interests, or surrendering our last scrap of independence to their total and complete control.” Id. 
contributions.”239 He said of a Republican donor and a primary opponent, "Sheldon Adelson is looking to give big dollars to Rubio because he feels he can mold him into his perfect little puppet. I agree!"240 He said of other opponents, "I wish good luck to all of the Republican candidates that traveled to California to beg for money etc. from the Koch Brothers. Puppets?”241

Trump called his Democratic opponent "Crooked Hillary,"242 and he addressed her roughly during the final debate of the campaign: "I sat there watching ad after ad after ad, false ad. All paid for by your friends on Wall Street that gave so much money because they know you're going to protect them."243

The presidential campaign of 2016 and its outcome revealed that the appearance of corruption in America is widespread and intense. Unfettered super PAC contributions have become, in the eyes of many, a potent symbol of America's deep corruption.

\section{Some Views of Elected Officials, Lobbyists, and Donors}

Like presidential candidates, federal officeholders, lobbyists, and super PAC donors have decried the corruption produced by America's campaign finance system. In 2015, former President Jimmy Carter said that America has become

an oligarchy, with unlimited political bribery being the essence of getting the nominations for president or to elect the president. And the same thing

239. Transcript of the Republican Debate in Florida, N.Y. TIMES (Mar. 11, 2016), https://www.nytimes.com/2016/03/11/us/politics/transcript-of-the-republican-presidentialdebate-in-florida.html [https://perma.cc/9QUC-PHDS]. In an earlier debate, Trump said, "I give to everybody. When they call, I give.... And do you know what? When I need something from them two years later, three years later, I call them, they are there for me.... And that's a broken system.” Annotated Transcript: The Aug. 6 GOP Debate, WASH. Post (Aug. 6, 2015), http://wapo.st/1JNEHtM?tid=ss_tw\&utm_term=.3f0b06747919 [https://perma.cc/M5CU-27KC]. In still another debate, Trump called super PACs "a scam" and said, "They cause dishonesty. And you better get rid of them because they are causing a lot of bad decisions to be made by some very good people. And I'm not blaming these folkswell, I guess I could.” Transcript: Republican Presidential Debate, N.Y. TIMES (Oct. 28, 2015), https://www.nytimes.com/2015/10/29/us/politics/transcript-republican-presidentialdebate.html [https://perma.cc/U7K2-6JYK].

240. Donald Trump, @realDonaldTrump, TwitTER (Oct. 13, 2015, 6:46 AM), https://twitter.com/realDonaldTrump/status/653884577300267008 [https://perma.cc/2MREVJKC].

241. Donald Trump, @realDonaldTrump, TwitTer (Aug. 2, 2015, 7:00 AM), https://twitter.com/realDonaldTrump/status/627841345789558788 [https://perma.cc/ALS5BGF2].

242. Amber Jamieson, Trump Calls Clinton "Crooked Hillary”-Should She Ignore It or Fight Back?, GuARDIAN (May 25, 2016, 12:38 PM), https://www.theguardian.com/usnews/2016/may/25/donald-trump-crooked-hillary-clinton-nickname-ignore-fight

[https://perma.cc/45BC-S7GL] (noting that Trump employed the insult at least fifty times within a six-week period).

243. Transcript of the Third Debate, N.Y. TIMEs (Oct. 20, 2016), https://www.nytimes.com/2016/10/20/us/politics/third-debate-transcript.html [https://perma.cc/ZY36-73FF]. For other Trump quotations in the same vein as those presented here, see Rick Claypool, Donald Trump, Clean Government Reformer?, PuB. CitizeN (Nov. 15, 2016), https://www.citizen.org/sites/default/files/trump-reform-quotesreport.pdf [https://perma.cc/E36D-NUFV]. 
applies to governors and U.S. senators and congress members. So now we've just seen a complete subversion of our political system as a payoff to major contributors, who want and expect and sometimes get favors for themselves after the election's over.244

Former Vice President Al Gore wrote in 2013 that “American democracy has been hacked" and that Congress "is now incapable of passing laws without permission from the corporate lobbies and other special interests that control their campaign finances."245

Representative Michele Bachmann spoke in 2011 of "the corrupt paradigm that has become Washington, D.C., whereby votes continually are bought rather than representatives voting the will of their constituents.”246

Senator John McCain, the Republican nominee for President in 2008, said in 2012, "What we have done is made a contribution limit a joke." He added, "I promise you, there will be huge scandals, because there's too much money washing around, too much of it we don't know who's behind it and too much corruption associated with that kind of money. There will be major scandals." 247

Senator John Kerry, the Democratic nominee for President in 2004, said in his last speech to the Senate before becoming Secretary of State in 2013, "The truth requires that we call the corrosion of money in politics what it is-it is a form of corruption and it muzzles more Americans than it empowers, and it is an imbalance that the world has taught us can only sow the seeds of unrest."248

Senator Lindsey Graham said in 2015, "We've got to figure out a way to fix this mess, because basically 50 people are running the whole show." 249

Senator Angus King said in 2016, "[W]e can look around the world where oligarchs control the government, and we're allowing that to happen here before our very eyes.”250

244. President Jimmy Carter: The United States Is an Oligarchy . ., Thom HarTmanN (July 28, 2015), https://www.thomhartmann.com/bigpicture/president-jimmy-carter-unitedstates-oligarchy [https://perma.cc/AQ7A-KGJ5].

245. Michiko Kakutani, Up Ahead: The World According to Gore, N.Y. TIMES (Jan. 23, 2013), http://www.nytimes.com/2013/01/24/books/the-future-by-al-gore.html [https://perma.cc/CG6Q-BTLY]

246. David A. Patten, Michele Bachmann: The Newsmax Interview, Newsmax (Jan. 26, 2011, 4:40 PM), http://www.newsmax.com/InsideCover/bachmann-newsmax-interviewromney/2011/06/26/id/401507/ [https://perma.cc/XY5M-56JE].

247. Alina Selyukh, John McCain Predicts “Huge Scandals” in the Super PAC Era, HufFINGTON Post (Dec. 6, 2017), http://www.huffingtonpost.com/2012/03/27/john-mccaincitizens-united-campaign-finance_n_1383230.html [http://perma.cc/85KJ-JNQA].

248. Seth Cline, Retiring Senators Lament Money in Politics: Senators Kerry, Harkin, and Levin All Decried the State of Campaign Finance in Retiring Remarks, U.S. NEws (Mar. 8, 2013, 3:19 PM), https://www.usnews.com/news/articles/2013/03/08/retiring-senators-lamentmoney-in-politics [https://perma.cc/W4RG-WLAR].

249. Andy Sullivan, Here's One White House Hopeful Who Wants to Get Big Money Out of Politics, Reuters (Apr. 18, 2015, 7:41 PM), http://www.reuters.com/article/us-usaelection-money-idUSKBNON90SY20150418?feedType=RSS\&feedName=politicsNews [https://perma.cc/JS7R-Y3NK].

250. King, Colleagues Unveil New Campaign Finance and Governmental Reform Package, ANGUS KING (June 9, 2016), https://www.king.senate.gov/newsroom/press- 
Senator Amy Klobuchar said in 2016, "This for me is the biggest issue of our time in our country because I have seen what this money has done to Washington."251

Jack Abramoff, a former lobbyist who served a prison term for bribery, said that, even apart from his illegal conduct, "I was participating in a system of legalized bribery. All of it is bribery, every bit of it."252

Even some billionaire donors view unlimited super PAC contributions as corrupting. Donald Sussman, who gave \$39 million to Democratic super PACs and allied groups in 2016,253 told the Washington Post, "It's very odd to be giving millions when your objective is to actually get the money out of politics."254 Sheldon Adelson, who gave $\$ 78$ million to Republican super PACs and allied groups in 2016,255 told an interviewer, "I'm against very wealthy people attempting to or influencing elections .... But as long as it's doable I'm going to do it."256

\section{E. Public Opinion}

Opinion surveys also indicate the depth of the appearance of corruption in America.257 In a 2015 Rasmussen survey, 59 percent of likely voters agreed

releases/king-colleagues-unveil-new-campaign-finance-and-governmental-reform-package[https://perma.cc/TZ5N-MVE4].

251. Ben Jacobs \& David Smith, "Politics Are Corrupt": Fears About Money and Its Influence on Elections Loom Large, GUARDIAN (July 8, 2016, 7:00 AM), https://www.theguardian.com/us-news/2016/jul/08/trump-clinton-sanders-super-pacselection-money [https://perma.cc/X6D3-VZC2].

252. LaWrence Lessig, Republic, Lost: How Money Corrupts Congress-AND A PLAN TO STOP IT 8 (2011).

253. See 2016 Top Donors to Outside Spending Groups, OpENSECRETS.ORG, https://www.opensecrets.org/outsidespending/summ.php?disp=D [https://perma.cc/8RXLNKYC] (last visited Mar. 15, 2018).

254. Matea Gold, Hedge Fund Manager S. Donald Sussman Gave $\$ 21$ Million to ProClinton Super PAC Priorities USA, WASH. Post (Oct. 20, 2016), http://wapo.st/2eWWjeB? tid=ss_tw\&utm_term=.ea9737a06ac8 [https://perma.cc/AT9N-AT2Y].

255. 2016 Top Donors to Outside Spending Groups, OpENSECRETS.ORG, https://www.opensecrets.org/outsidespending/summ.php?disp=D [https://perma.cc/R9NSYDQW] (last visited Mar. 15, 2018).

256. Steven Bertoni, Billionaire Sheldon Adelson Says He Might Give \$100M to Newt Gingrich or Other Republican, ForBes (Feb. 21, 2012, 12:04 AM), https://www.forbes.com/sites/stevenbertoni/2012/02/21/billionaire-sheldon-adelson-says-hemight-give-100m-to-newt-gingrich-or-other-republican/\#51757f934400 [https://perma.cc/ 6H7T-KNHB].

257. A Court that looks to the appearance of corruption as the test of Congress's power to limit political contributions cannot reasonably dismiss polls showing that this appearance is pervasive. In other contexts, however, judges do not bend to opinion polls, and the McCutcheon plurality declared that it would brave public opinion on campaign finance issues as well:

Money in politics may at times seem repugnant to some, but so too does much of what the First Amendment vigorously protects. If the First Amendment protects flag burning, funeral protests, and Nazi parades-despite the profound offense such spectacles cause - it surely protects political campaign speech despite popular opposition.

McCutcheon v. FEC, 134 S. Ct. 1434, 1441 (2014) (plurality opinion). In our view, this passage reflects an error that has infected much of the Supreme Court's campaign finance jurisprudence. The First Amendment protects Nazi parades and other offensive speech, but 
that most members of Congress were "willing to sell their vote for either cash or a campaign contribution." 258 Fifty-six percent thought it likely that their own representatives had done so. 259

Fifty-four percent of the respondents to a 2012 Pew Research Center survey described the United States government as "mostly corrupt."260

In a 2010 survey by the Center for Competitive Politics, 65 percent of respondents agreed that a contribution of $\$ 10,000$ or more could exert a corrupting influence on a candidate for Congress. 261

In a 2012 survey by Democracy Corps and the Public Campaign Action Fund, 59 percent of voters in fifty-four competitive congressional districts agreed that " $[\mathrm{w}]$ hen someone gives one million dollars to a Super PAC, they want something big in return from the candidates they are trying to elect."262

A 2012 Brennan Center for Justice survey focused specifically on super PACs. It reported that 69 percent of respondents (74 percent of Republicans and 73 percent of Democrats) agreed that "new rules that allow individuals, corporations, and unions to donate unlimited amounts [of money] to Super PACs will lead to corruption.”263 Seventy-three percent of respondents (75 percent of Republicans and 78 percent of Democrats) agreed that "there would be less corruption if there were limits on how much could be given to Super PACs."264 Sixty-eight percent of respondents (71 percent of Democrats and 71 percent of Republicans) agreed that "a company that spent

the public does not oppose money in politics because it is offended by the content of the messages this money may send- “vote Democratic” or "vote Republican.” Rather, the public is troubled because campaign cash can persuade elected officials in the same way that expensepaid trips to the Super Bowl can persuade them, and persuasion of that kind is entitled to no First Amendment protection. We believe that speech-facilitating activity should not be entitled to a strong presumption of constitutional protection when the reason for limiting it is unrelated to the message it advances. See, e.g., United States v. O’Brien, 391 U.S. 367, 376 (1968); John Hart Ely, Comment, Flag Desecration: A Case Study in the Roles of Categorization and Balancing in First Amendment Analysis, 88 HARV. L. REv. 1482, 1491502 (1975). Nevertheless, we leave that proposition for another day and simply note that the McCutcheon plurality was not entitled to claim the anticensorship mantle of Milton, Mill, Holmes, and Brandeis. Regulating political contributions and expenditures in an effort to prevent quid pro quo corruption is not remotely analogous to suppressing unpopular speech.

258. Is Congress for Sale?, RASSMUSSEN REPORTS (July 9, 2015), http://www.rasmussenreports.com/public_content/archive/mood_of_america_archive/congre ssional_performance/is_congress_for_sale [https://perma.cc/QMT9-784J].

259. Id.

260. Growing Gap in Favorable Views of Federal, State Governments, PEW RES. CTR. (Apr. 26, 2012), http://www.people-press.org/files/legacy-pdf/4-26-12\%20Govt\%20 Favorability.pdf [https://perma.cc/W659-2GPY].

261. Jason M. Farrell \& Nima Veiseh, Public Perception and the “Appearance of CORRUPTION” IN CAMPAIGN FINANCE 7-8 (2011), http://www.campaignfreedom.org/wpcontent/uploads/2012/11/Public-Perception-and-the-Appearance-of-Corruption-inCampaign-Finance-Report-Final.pdf [https://perma.cc/ANM2-CN6Z].

262. Memorandum from Stan Greenberg et al., to the Friends of Democracy Corps et al. 4 (Oct. 1, 2012), http://www.democracycorps.com/attachments/article/910/dcor.pcaf.memo. 093012.v4.pdf [https://perma.cc/WH8Y-59W2].

263. National Survey: Super PACs, Corruption, and Democracy, BRENNAN CTR. FOR JUST. (Apr. 24, 2012), https://www.brennancenter.org/analysis/national-survey-super-pacscorruption-and-democracy [https://perma.cc/4N32-5FRZ].

264. Id. 
$\$ 100,000$ to help elect a member of Congress could successfully pressure him or her to change a vote on proposed legislation.”265

In a March 2012 ABC News/Washington Post survey, 69 percent of respondents stated that super PACs should be illegal.266

A 2016 University of Maryland survey reported that 89 percent of registered voters (92 percent of Trump supporters and 88 percent of Clinton supporters) agreed that "elected officials think more about the interests of their campaign donors than the common good of the people.”267 Eighty-five percent of these voters (82 percent of Trump supporters and 90 percent of Clinton supporters) favored "trying to reduce the amount of money flowing into political campaigns and Super PACs."268

The Supreme Court said in Citizens United, "[T]he appearance of influence or access will not cause the electorate to lose faith in this democracy."269 Eight years after Citizens United and SpeechNow, however, faith in our democracy appears to be at a nadir. The polling data reveal that unlimited super PAC contributions have played a significant part in intensifying public perceptions of corruption. 270

\section{Challenging SPEECHNOW}

When a presidential candidate promises to appoint Supreme Court Justices who will overrule Citizens United, 271 her audience may imagine that Citizens United would not last long if the candidate were elected and kept her promise. Whenever a majority of the Court was prepared to overrule Citizens United, someone would bring an appropriate case, and the decision would vanish. The obstacles to bringing an appropriate case, however, are substantial. Whatever its composition, the Supreme Court may not have an opportunity to overrule Citizens United.

Similarly, although the Court has not addressed the issue decided by SpeechNow, it may never be able to do so. The authors of this Article are among the lawyers currently representing members of Congress and candidates for Congress who are attempting to bring this issue before the

265. Id.

266. See Damla Ergun, Seven in 10 Would Send Super PACs Packing, YAHOO! (Mar. 13, 2012), https://www.yahoo.com/gma/seven-10-send-super-pacs-packing-110203334—abcnews.html [https://perma.cc/5DRD-ZZU8]; Washington Post-ABC News Poll, WAsH. PosT (Mar. 10, 2012), http://www.washingtonpost.com/wp-srv/politics/polls/postabcpoll_ 031012.html [https://perma.cc/RU56-LCTR].

267. See Voice of the PeOPLe, supra note 183, at 8.

268. Id. at 8,16 .

269. Citizens United v. FEC, 558 U.S. 310, 314 (2010).

270. See generally Rebecca Brown \& Andrew D. Martin, Rhetoric and Reality: Testing the Harm of Campaign Spending, 90 N.Y.U. L. REV. 1066 (2015) (purporting to demonstrate empirically the inaccuracy of the Supreme Court's claim that the appearance of influence or access caused by large political contributions does not cause a loss of faith in democracy).

271. See Transcript, Hillary Clinton's DNC Speech, Annotated, supra note 232. Of course popular rhetoric does not distinguish between Citizens United and SpeechNow. Politicians and the public blame Citizens United for super PACs and everything else they dislike about our system of campaign financing. 
Court. The Federal Election Commission is opposing their efforts on grounds that, if successful, could keep the Court from ever deciding the issue.

A court's ability to reconsider a decision upholding a statute differs from its ability to reconsider a decision striking a statute down. When a court upholds a challenged statute, its ruling binds the party who has challenged this statute, but someone else threatened with enforcement can bring another challenge and ask the court to overrule its earlier decision. If this party fails, a third party can bring a third challenge. The challengers of a statute can keep trying until victory is won. Citizens United, which overruled two prior decisions upholding federal election laws, illustrates the process. 272

Once a court holds a statute unconstitutional, however, enforcement of the statute usually comes to a halt. Nonenforcement of the statute then becomes an injury shared by all members of the public, and no one may have standing to challenge it.273 The law of standing may thus place decisions about the constitutionality of statutes on a one-way ratchet. Any triumph of a statute's defenders may prove transient, but any triumph of a challenger (even at the hands of a closely divided Supreme Court) may prove permanent and incontestable. Constitutional litigation can become a game of sudden death, but only for one side. Although a presumption of constitutionality is thought to tilt the game board against litigants who challenge a statute's constitutionality,274 the law of standing appears to tilt the board in the opposite direction.

When the Justice Department failed to seek Supreme Court review of SpeechNow 275 and the FEC acquiesced in this decision,276 the enforcement of federal limits on super PAC contributions ceased. For a time, several states and one municipality continued to enforce their own limits, but the federal courts of appeals sustained challenges to their efforts.277 None of the states sought Supreme Court review, 278 and the petition for certiorari filed by the municipality did not address the SpeechNow syllogism the Court of Appeals

272. See Citizens United, 558 U.S. at 365-66 (overruling Austin v. Mich. Chamber of Commerce, 494 U.S. 652 (1990), and a portion of McConnell v. FEC, 540 U.S. 93 (2003)).

273. See, e.g., Schlesinger v. Reservists Comm. to Stop the War, 418 U.S. 208, 217 (1974) (denying standing to litigants who sought to assert "only the generalized interest of all citizens in constitutional governance"); United States v. Richardson, 418 U.S. 166, 177 (1974) (denying standing because the injury asserted was "undifferentiated and 'common to all members of the public”” (quoting Ex parte Lévitt, 302 U.S. 633, 634 (1937) (per curiam))); Perkins v. Lukens Steel Co., 310 U.S. 113, 125 (1940) (holding that litigants must show injury to "a particular right of their own, as distinguished from the public's interest in the administration of the law”); Frothingham v. Mellon, 262 U.S. 447, 488 (1923) (declaring it insufficient that a litigant "suffers in some indefinite way in common with people generally").

274. See, e.g., O’Gorman \& Young, Inc. v. Hartford Fire Ins. Co., 282 U.S. 251, 257-58 (1931).

275. See supra note 36 and accompanying text.

276. See FEC, Advisory Opinion 2010-11, supra note 32.

277. See supra note 31 and accompanying text.

278. See Email from Jonathan Mitchell, Solicitor Gen. of the State of Tex., to Albert Alschuler (Dec. 21, 2013) (on file with the Fordham Law Review); Letter from Brian A. Sutherland, Assistant Solicitor Gen. of the State of N.Y., to Mae A. D’Agostino, Judge of the U.S. Dist. Court for the N. Dist. of N.Y. (May 23, 2014) (on file with the Fordham Law Review). 
had endorsed. Indeed, this petition did not include SpeechNow among the five cases it cited.279

With the denial of the municipality's petition and the failure of the states to seek review, the path to the Supreme Court seemed almost closed. Nevertheless, John Bonifaz, president of the public-interest organization Free Speech for People, Ronald A. Fein, the group's legal director, and some volunteer lawyers including the authors of this Article sought ways to bring the constitutionality of limiting super PAC contributions before the Court.

One potential route to Supreme Court review was the enactment of legislation incompatible with the right declared by SpeechNow. A stream of legislation following Roe v. Wade280 has given the Court repeated opportunities to overrule that decision. Defenders of post-Roe restrictions on abortion can argue that these restrictions are consistent with Roe or, in the alternative, that Roe should be overruled. Unlike Roe, however, SpeechNow did not create a right whose boundaries were uncertain. Legislatures can resist SpeechNow only by enacting and enforcing limits on super PAC contributions similar to those the D.C. Circuit struck down.

Free Speech for People encourages legislatures to enact these limits, especially in places where federal courts of appeals have not yet ruled on their validity. Unlike some legislative efforts to limit abortion, these limits would not defy the courts' authority; they might instead enable the Supreme Court to consider an issue it has not yet addressed.

In October 2017, the St. Petersburg, Florida, city council approved an ordinance limiting super PAC contributions drafted primarily by Mr. Fein.281

279. See Petition for Writ of Certiorari, City of Long Beach v. Long Beach Area Chamber of Commerce, 562 U.S. 896 (2010) (No. 10-155). The Ninth Circuit argument on the validity of the Long Beach ordinance limiting super PAC contributions occurred three months before the Supreme Court's decision in Citizens United. After Citizens United and before SpeechNow, the parties filed supplemental briefs on the significance of Citizens United. The Ninth Circuit decided the case on April 30, 2010, a little more than a month after the D.C. Circuit decided SpeechNow. See Long Beach Area Chamber of Commerce v. City of Long Beach, 603 F.3d 684 (9th Cir. 2010). The court quoted and relied on the SpeechNow syllogism. Id. at 697-98.

The Long Beach ordinance presented the validity of limiting contributions to super PACs in a peculiar way. It did not directly impose any limit, and a contributor could not violate the ordinance. The ordinance, however, forbade a super PAC that accepted contributions in excess of certain specified amounts from making any expenditure. The Ninth Circuit was uncertain whether this ordinance imposed contribution limits or an expenditure limit, but it concluded that the SpeechNow syllogism made that issue immaterial. Id. at 692-93, 697-98. The prevailing party in the Ninth Circuit did not respond to the city's petition for certiorari, and the Supreme Court did not request a response. The Court denied certiorari on the first day of its October 2010 term, approximately eight months after it decided Citizens United. See City of Long Beach, 562 U.S. 896.

280. 410 U.S 113 (1973).

281. See St. Petersburg Passes Anti-Super PAC Ordinance, Hoping to Set Up Constitutional Showdown, NAT’L. L. REV. (Oct. 6, 2017), https://www.natlawreview.com/ article/st-petersburg-passes-anti-super-pac-ordinance-hoping-to-set-constitutional-showdown [https://perma.cc/5S4N-38S4]; see also Darden Rice \& Scott Greytak, Column: Keep Super PAC Cash out of St. Petersburg Elections, TAMPA BAY Times (July 15, 2016, 9:10 PM), http://www.tampabay.com/opinion/columns/column-keep-super-pac-cash-out-of-stpetersburg-elections/2285582 [https://perma.cc/Y6ZN-UBFU]; Editorial, Good Campaign Finance Idea-If It Won't Cost St. Petersburg Taxpayers, TAMPA BAY TimEs (Nov. 11, 2016), 
A few months earlier, the Connecticut House of Representatives voted to approve legislation limiting super PAC contributions,282 but the legislative session ended without action by the Senate. Legislation limiting super PAC contributions is currently under consideration in Massachusetts.283 Equal Citizens, a nonprofit group founded by Harvard Law Professor Lawrence Lessig, has announced that it will attempt to bring the SpeechNow issue before the Supreme Court by challenging the failure of the Alaska Attorney General to enforce existing Alaska laws limiting super PAC contributions.284

Federal election law provided another potential route to Supreme Court review. Although the failure to enforce a statute is usually seen as an injury shared by everyone and challengeable by no one, there are exceptions, and the 1974 statute establishing the FEC created one of these exceptions.

The Federal Election Campaign Act of 1971 (FECA), as amended by the 1974 statute and other enactments, provides that anyone may complain to the FEC about any violation of federal election law and that anyone "aggrieved" by either the dismissal of his complaint or the failure of the Commission to act within 120 days may secure a judicial ruling on whether the FEC's action or inaction is "contrary to law." 285

The Supreme Court has held that federal courts may afford review in accordance with these provisions when a complainant satisfies Article III standing requirements. 286 The complainant must show among other things a threat of "injury in fact" that is "fairly traceable" to the agency's failure to enforce the law. The "injury in fact" requirement imposed by Article III is thought to be more demanding than the statutory requirement that the complainant be a "party aggrieved."287

The ability of private parties to secure judicial enforcement of federal election law is a crucial part of FECA's enforcement mechanism. FECA provides that no more than three of the FEC's six members may be members of the same party.288 Four members must agree before the agency can act,289 and the agency is widely regarded as dysfunctional.290 One current FEC

\footnotetext{
http://www.tampabay.com/opinion/editorials/editorial-good-campaign-finance-idea-8212-ifit-wont-cost-st-petersburg/2302523 [https://perma.cc/W4Y4-VYXE].

282. Christine Stuart, Divided Connecticut House Forwards Campaign Bill to Senate, New HAVEN REG. (May 25, 2017), http://www.nhregister.com/government-andpolitics/20170525/divided-connecticut-house-forwards-campaign-bill-to-senate [https://perma.cc/E53E-B35D].

283. See H.D. 2082, 190th Gen. Court (Mass. 2017).

284. See Against Super PACs, EQUAL CITIZENS, https://equalcitizens.us/againstsuperpacs/?utm_source=Equal+Citizens+-+a+Lessig+project\&utm_campaign=14d5e0cdeeEMAIL_CAMPAIGN_2018_02_01\&utm_medium=email\&utm_term=0_3f0cb70adb14d5e0cdee-105268177 [https://perma.cc/8H2W-NFFT] (last visited Mar. 15, 2018).

285. 52 U.S.C. § 30109(a)(1), (a)(8)(A), (a)(8)(C) (2012).

286. FEC v. Akins, 524 U.S. 11, 12 (1998).

287. Id. at 19-21.

288. 52 U.S.C. § 30106(a)(1).

289. Id. § 30106(c).

290. See, e.g., Robin Bravender \& Dave Levinthal, FEC Dysfunction-It's Personal, PoliTiCO (Dec. 13, 2011, 11:40 PM), http://www.politico.com/story/2011/12/the-fecshealthy-ugly-discourse-070396 [https://perma.cc/YEW3-2PRW]; Ann M. Ravel, Dysfunction and Deadlock at the Federal Election Commission, N.Y. Times (Feb. 20, 2017),
} 
Commissioner commented, "Congress set this place up to gridlock.... This agency is functioning as Congress intended." 291 When the FEC fails to enforce the law, however, citizens may go to court.

The people most clearly threatened with injury in fact by the FEC's acquiescence in SpeechNow and its failure to enforce the federal limits on contributions to super PACs are candidates for federal office-especially candidates opposed by super PACs that receive contributions above the limit. Free Speech for People identified six elected officeholders and candidates who wished to challenge the FEC's failure to enforce the limit. They were Representative Ted Lieu (D-Cal.); Representative Walter Jones (R-N.C.); Senator Jeff Merkley (D-Or.); former state Senator John Howe, a Republican candidate for Congress in Minnesota; Michael Wager, a Democratic candidate for Congress in Ohio; and Zephyr Teachout, a Democratic candidate for Congress in New York.292 A number of lawyers volunteered to work with Free Speech for People in representing these complainants, including Anne Weismann, Stephen A. Weisbrod, Brad Deutsch, Malcolm Seymour, Andrew Goodman, and us.

On July 7, 2016, with the general election campaigns of 2016 barely underway, Representative Lieu and the others filed their complaint with the FEC.293 The FEC might have dismissed this complaint promptly, citing its earlier acquiescence in SpeechNow. The complainants then could have sought review in the U.S. District Court for the District of Columbia. That court, which was bound to follow SpeechNow, also might have denied relief quickly. The complainants then could have appealed to the court of appeals and urged it to overrule SpeechNow. The likelihood that the court of appeals would overrule its unanimous en banc decision was small, however, and a three-judge panel of the court would not have had authority to do so.294 If the court of appeals denied relief, the complainants could have sought Supreme Court review. This path to Supreme Court review may look straightforward, but it is filled with booby traps.

The statutory period of 120 days ended without an FEC ruling, and little agency activity seems to have occurred within this period. The Lieu

https://www.nytimes.com/2017/02/20/opinion/dysfunction-and-deadlock-at-the-federalelection-commission.html [https://perma.cc/8RVS-9VE9]; Eliza Newlin Carney, The FEC's Open Hostilities, Dysfunction, and Intimidation Foreshadowed the Trump Era, AM. PROSPECT (Mar. 2, 2017), http://prospect.org/article/fec\%E2\%80\%99s-open-hostilities-dysfunctionand-intimidation-foreshadowed-trump-era [https://perma.cc/7W6C-2944]; Will Tucker, The

FEC: "Acting” Like an Enforcement Agency, OpEnSECRETS.ORG (June 17, 2016), https://www.opensecrets.org/news/2016/06/the-fec-acting-like-an-enforcement-agency/ [https://perma.cc/TA2N-8988].

291. Eric Lichtblau, F.E.C. Can't Curb 2016 Election Abuse, Commission Chief Says, N.Y. TiMES (May 2, 2015), https://www.nytimes.com/2015/05/03/us/politics/fec-cant-curb-2016election-abuse-commission-chief-says.html [https://perma.cc/WYQ8-TJNB].

292. Complaint, Lieu v. House Majority PAC, MUR No. 7101 (FEC dismissed May 25, 2017), https://freespeechforpeople.org/wp-content/uploads/2016/07/FINAL-FEC-ComplaintPDF-7-7-16.pdf [https://perma.cc/3GMH-Y8LW].

293. Id.

294. See LaShawn A. v. Barry, 87 F.3d 1389, 1395 (D.C. Cir. 1996) (“One three-judge panel ... does not have the authority to overrule another three-judge panel of the court.”). 
complaint listed as respondents ten super PACs that had campaigned against one or more of the complainants and that had accepted contributions above the statutory limit.295 It noted thirty-nine contributions above the limit from twenty-seven contributors these super PACs had received. After receiving the complaint, the FEC invited responses not only from the named respondents but also from all of the contributors identified in the complaint. Many of the mostly well-known law firms representing the contributors and the super PACs then sought extensions of time, and twenty-two ultimately filed responses to the complaint.296

The responses of many contributors expressed bafflement that the FEC had invited their responses although they were not respondents. Under FECA, the FEC need not invite responses even from named respondents before dismissing a complaint.297 No response denied what the FEC's public records and the respondents' own disclosures revealed - that the respondents did accept contributions above the limit, just as SpeechNow and an FEC advisory opinion authorized them to do.

A few responses sharply criticized the complainants. Lawyers representing the House Majority PAC, the Senate Majority PAC, and several individual contributors to super PACs supporting Democrats wrote:

[I]t is lucky for complainants that the Commission has never adopted a sanction for frivolous filings because this would surely fail the threshold for a good faith complaint.... [I]n order to discourage similar stunts in the future, we suggest the Commission indicate in the close out letter that this was a frivolous complaint that wasted government and private resources. ${ }^{298}$

Perhaps these lawyers would have had equally harsh words for Thurgood Marshall and the other NAACP lawyers who in 1951 filed a lawsuit challenging school segregation-a suit that could not have succeeded in the district court in light of Plessy v. Ferguson 299 and other precedents allowing racial segregation. 300 Perhaps these lawyers also would have considered sanctions appropriate for the FEC at the time of the SpeechNow litigation. In SpeechNow, the agency defended the constitutionality of limits on

295. Complaint, supra note 292.

296. The firms representing respondents and contributors included Jones Day; Perkins Coie; Covington \& Burling; Wiley Rein; Skadden, Arps, Slate, Meagher \& Flom; Caplin \& Drysdale; Rose Law Firm; and Arnold \& Porter Kaye Scholer. Their responses are available online. See MUR \#7101, FED. ELECTION COMM’n, https://www.fec.gov/data/legal/matterunder-review/7101/ [https://perma.cc/NC5D-MATC] (last visited Mar. 15, 2018).

297. See 52 U.S.C. § 30109(a)(1) (2012) ("Before the Commission conducts any vote on the complaint, other than a vote to dismiss, any person so notified shall have the opportunity to demonstrate, in writing, ... that no action should be taken ....” (emphasis added)); 11 C.F.R. § 111.5(a) (2018) (requiring notice of a complaint only for respondents).

298. Letter from Marc E. Elias, Ezra W. Reese, and Katherine T. LaBeau, to Jeff S. Jordan, Office of Gen. Counsel, Fed. Election Comm'n (Sept. 6, 2016), http://eqs.fec.gov/ eqsdocsMUR/17044420697.pdf [https://perma.cc/669L-LRKR].

299. 163 U.S. 537 (1896).

300. See Brown v. Bd. of Educ., 347 U.S. 483 (1954) (overruling Plessy). 
contributions to super PACs although the D.C. Circuit had already held in EMILY's List v. FEC301 that these limits were unconstitutional.302

As the lawyers for the House Majority PAC and the Senate Majority PAC contended, the Lieu complaint led to a waste of government and private resources. We cannot guess how many thousands of dollars they and other lawyers charged their clients for filing responses describing law the plaintiffs had acknowledged in their complaint.

On November 4, 2016, four days before Election Day, the complainants filed suit against the FEC in the U.S. District Court for the District of Columbia.303 They alleged that the agency's failure to act within the 120day period was, in the words of the applicable statutory standard, "contrary to law."304

On reading the statute, one might have thought that the FEC's failure to act would be contrary to law if it had failed to enforce the law-in other words, if it had not acted on a meritorious complaint within 120 days. This straightforward reading would have allowed complainants to seek judicial enforcement when the agency itself did not enforce the law promptly. Congress apparently realized that, when the remedy for an election-law violation comes after an election, it is likely to come too late. 305

In 1986, however, the D.C. Circuit rejected the view that the FEC's inaction can be contrary to law simply because the agency failed to enforce the law. 306 It also declined to impose a requirement or even a presumption that the FEC must rule on a complaint within a single election cycle. 307 The court held that the agency's failure to act on a complaint is contrary to law only when its delay has been arbitrary and capricious. ${ }^{308}$ It added that a judge should consider the resources available to the agency, the press of other business, the complexity of the case, and other circumstances in determining whether the agency's delay has been arbitrary and capricious. 309

The FEC filed an answer to the complainants' (now plaintiffs') lawsuit. It also sought and obtained a protective order to prevent the plaintiffs from disclosing confidential information they might receive during the litigation. It served interrogatories asking the plaintiffs to describe how they had been injured by its nonenforcement of the limits on super PAC contributions. The plaintiffs served interrogatories inquiring about the reasons for the FEC's delay and the actions it had taken since they filed their complaint.

301. 581 F.3d 1 (D.C. Cir. 2009).

302. Id. at 8-11.

303. See Matea Gold, Legal Team Seeking to Undo Super PACs Files Suit to Push FEC to Act, WAsH. Post (Nov. 4, 2016), https://www.washingtonpost.com/news/post-politics/wp/ 2016/11/04/legal-team-seeking-to-undo-super-pacs-files-suit-to-push-fec-to-act/ [https://perma.cc/A84F-SKJT].

304. 52 U.S.C. § 30109(a)(8)(C) (2012).

305. See, e.g., id. $\S 30108(a)(2)$ (requiring the FEC to issue an advisory opinion within twenty days when a candidate has requested this opinion within sixty days of an election).

306. FEC v. Rose, 806 F.2d 1081, 1084 (D.C. Cir. 1986).

307. Id. at $1084-85$.

308. Id.

309. Id. at $1084 \&$ n.6. 
On June 1, 2017, nearly eleven months after the plaintiffs filed their administrative complaint, the FEC sent a letter rejecting it.310 After receiving the letter, the plaintiffs moved to amend their district court complaint to challenge the FEC's rejection of their administrative complaint. The FEC opposed this motion, and, at the time of this writing (March 2018), the court has not ruled. 311

A plaintiff's standing is ordinarily judged at the time a complaint is filed. 312 By forcing the plaintiffs to refile their complaint rather than amend it, the FEC apparently hopes to move the date for assessing their standing from shortly before the election of 2016 (a time when some plaintiffs were actively opposed by super PACs that accepted contributions above the limit) to more than a year after the election.

Of course, if the FEC had rejected the plaintiffs' complaint within 120 days, no one could have doubted the appropriateness of a determination of standing on the pre-election date. Refusing an amendment would reward the FEC's delay in dismissing the complaint and encourage it to delay in other cases. Whenever a candidate sought prospective relief, the FEC might delay action on his case until after Election Day in the hope that his ability to challenge an adverse ruling would vanish.

The FEC argues that, because the district court complaint challenging the agency's unlawful delay is now moot, the court lacks jurisdiction to amend the complaint. The agency thus maintains that its ruling deprived the plaintiffs of the ability to challenge its delay (by making the delay moot) while its delay deprived them of the ability to challenge its ruling (by pushing the date for determining their standing beyond Election Day).313 This sort of bind is called a Catch-22.314

310. See FEC Dismisses Lawmakers' Complaint Against Super PACs, BloOMBERG (June 15, 2017), https://www.bna.com/fec-dismisses-lawmakers-n73014453387/ [https://perma.cc/ D2HP-9YU8].

311. The remainder of this Part offers an overview of the arguments the parties have made concerning the plaintiffs' motion to amend. These arguments are found in three documents filed in Lieu v. FEC, No. 16 Civ. 2201 (EGS) (D.D.C. filed Nov. 14, 2016): Memorandum in Support of Plaintiffs' Motion for Leave to File Amended Complaint, Lieu, No. 16 Civ. 2201 (EGS) (D.D.C. June 22, 2017), ECF No. 21-1; Federal Election Commission's Opposition to Plaintiffs' Motion for Leave to File Amended Complaint, Lieu, No. 16 Civ. 2201 (EGS) (D.D.C. July 17, 2017), ECF No. 25; Plaintiffs' Reply in Support of Motion for Leave to File Amended Complaint, Lieu, No. 16 Civ. 2201 (EGS) (D.D.C. Aug. 16, 2017), ECF No. 28. Our goal is not to explore the arguments in depth but simply to show what an obstacle course the plaintiffs must navigate to secure the D.C. Circuit's reconsideration and the Supreme Court's review of SpeechNow.

312. See, e.g., Friends of the Earth, Inc. v. Laidlaw Envtl. Servs., 528 U.S. 167, 190-91 (2000); Hardaway v. D.C. Hous. Auth., 843 F.3d 973, 978 (D.C. Cir. 2016).

313. The plaintiffs respond that, because the FEC's delay is capable of repetition and likely to evade review, the initial complaint is not moot. See, e.g., Del Monte Fresh Produce Co. v. United States, 570 F.3d 316, 324-35 (D.C. Cir. 2009) (holding that a claim of unreasonable delay in issuing a license was not mooted by issuance of the license because the agency was likely to engage in similar delay when the plaintiff sought other licenses). The plaintiffs also note that when action by the government renders an initial complaint moot, the Supreme Court has allowed plaintiffs to amend their complaint to challenge the new governmental action. Diffenderfer v. Cent. Baptist Church of Miami, 404 U.S. 412, 415 (1972) (per curiam).

314. See Joseph Heller, CATCH-22 (1955). 
The FEC also argues that the court should refuse to allow amendment because amendment would be futile; it contends that the amended complaint would be subject to dismissal on several grounds. The plaintiffs respond that a complaint is not always futile simply because a trial court must dismiss it. In 1951, for example, Supreme Court precedent required a trial court to deny relief to the plaintiffs in Brown v. Board of Education,315 but the complaint of these plaintiffs changed history. The plaintiffs argue that the court should exercise its discretion to amend the complaint before considering whether to dismiss it.

The FEC argues that its acquiescence in SpeechNow would be "contrary to law" only if its decision was "arbitrary or capricious or an abuse of discretion." The plaintiffs maintain that "arbitrary or capricious" is the standard of review only when an agency is entitled to deference of one sort or another. They say that, when a ruling on a purely legal question is entitled to neither Chevron deference316 nor Skidmore deference,317 it is entitled to no deference at all.

The FEC claims that, whether or not its acquiescence in SpeechNow was contrary to law, it was required to dismiss the plaintiffs' complaint. In an advisory opinion sought by a super PAC, it had authorized super PACs to accept contributions above the statutory limit,318 and FECA provides that someone who relies in good faith on an FEC advisory opinion "shall not ... be subject to any sanction provided by this Act."319 Although the plaintiffs have sought only declaratory relief, the FEC maintains that declaratory relief is itself a sanction. Because the agency's advisory opinion deprived it of the ability to impose this supposed sanction, the FEC was required to reject the plaintiffs' complaint.

The FEC's position abandons the usual meaning of the word "sanction"a penalty or detriment imposed for violation of a legal requirement. 320 Moreover, judicial acceptance of the FEC's conclusion would provide a way for the agency to insulate all rulings allowing unlawful practices from judicial review. It would be enough for the agency to announce its rulings in advisory opinions. FECA, however, allows courts to review FEC failures to enforce the law,321 and a construction of the statute that would allow the FEC to nullify this provision cannot be correct.

315. 98 F. Supp. 797 (D. Kan. 1951) (citing Gong Lum v. Rice, 275 U.S. 78 (1927); Plessy v. Ferguson, 163 U.S. 537 (1896)), rev’d, 347 U.S. 483 (1954).

316. See Chevron U.S.A. Inc. v. Nat. Res. Def. Council, 467 U.S. 837, 842-43 (1984) (affording deference when an agency construes a "statute which it administers").

317. See Skidmore v. Swift \& Co., 323 U.S. 134, 140 (1944) (affording deference when an agency has relevant expertise a court lacks).

318. See FEC, Advisory Opinion 2010-11, supra note 32.

319. 52 U.S.C. § 30108(c)(2) (2012).

320. See, e.g., Alabama v. North Carolina, 560 U.S. 330, 340 (2010) (“A 'sanction' (in the sense the word is used here) is ' $\mathrm{t}$ ] ]he detriment loss of reward, or other coercive intervention, annexed to a violation of a law as a means of enforcing the law." (alteration in original) (quoting Sanction, WeBSTER's NEw InTERNATIONAL DiCTIONARY 2211 (2d ed. 1954))).

321. 52 U.S.C. § 30109(a)(8)(C). 
The FEC maintains that, because its advisory opinion authorized the respondents' conduct, it could not find this conduct unlawful. In this argument, the FEC appears to enter the realm of legal philosophy, agreeing with some legal positivists that any conduct not subject to legal sanction is lawful. From this perspective, if diplomats have immunity from legal sanctions when they commit murder, it is lawful for diplomats to murder.

Just as FECA bars administrative sanctions when people have relied on FEC advisory opinions, a number of doctrines bar criminal punishment when defendants have relied reasonably on apparently authoritative assurances that their conduct would be lawful. These doctrines have such names as "official authorization,"322 “entrapment by estoppel,"323 “advice of counsel,"324 and "mistake of law."325 Although these doctrines sometimes excuse an actor's conduct, the conduct remains unlawful.326 A mistake of law does not change the law - not even when it rests on an advisory opinion issued by the FEC.327

When the plaintiffs sought declaratory relief from the FEC, they expected not to get it. The chance of victory before their case reached the Supreme Court was small. The plaintiffs, however, have been required to fight many battles just to keep their case on the track that heads toward the Court. The FEC's strenuous efforts, not to defend its actions but to block any review of its actions, may bring to mind such classics as Charles Dickens's Bleak House, 328 Rod Serling's The Twilight Zone,329 and Philip K. Howard's The Death of Common Sense.330 Lieu v. FEC shows how burdensome and ridiculous federal procedure has become.

Skirmishes in the back alleys of federal procedure will continue in Lieu $v$. FEC for some time. If the FEC succeeds in delivering a fatal blow to the

322. See Keathley v. Holder, 696 F.3d 644, 646-47 (7th Cir. 2012).

323. See Raley v. Ohio, 360 U.S. 423, 426 (1959); United States v. Tallmadge, 829 F.2d 767, 773-75 (9th Cir. 1987).

324. See United States v. DeFries, 129 F.3d 1293, 1308 (D.C. Cir. 1997).

325. See United States v. Albertini, 830 F.2d 985, 989 (9th Cir. 1987) ("[T]he government argued that mistake of law is never a defense. There is an exception to the mistake of law doctrine, however, in circumstances where the mistake results from the defendant's reasonable reliance upon an official-but mistaken or later overruled-statement of the law.”). United States v. Qualls, 172 F.3d 1136 (9th Cir. 1999), arguably overruled Albertini's conclusion that a defendant's reliance on a judicial decision was reasonable, but it did not question Albertini's description of the mistake of law defense.

326. The D.C. Circuit has held, for example, that a defendant charged with a specific-intent crime "is entitled to an advice-of-counsel instruction if he introduces evidence showing: (1) he made full disclosure of all material facts to his attorney before receiving the advice at issue; and (2) he relied in good faith on the counsel's advice that his course of conduct was legal.” DeFries, 129 F.3d at 1308. Although a lawyer's erroneous advice can thus give his client a defense, a lawyer's advice cannot amend the law.

327. See H.L.A. HART, THE CONCEPT OF LAW 139 (1961) (noting the inaccuracy of reducing law to the proposition that "[t]he score is what the scorer says it is").

328. Charles DiCKens, BleAK House (Nofton 1996) (1853).

329. See Adrienne LaFrance, How The Twilight Zone Predicted Our Paranoid Present, ATLANTIC (Dec. 31, 2013), https://www.theatlantic.com/entertainment/archive/2013/12/howem-the-twilight-zone-em-predicted-our-paranoid-present/282700/ [https://perma.cc/3WZ6P4JX] (describing the television series that ran from 1959 through 1964).

330. Philip K. Howard, The Death of Common Sense: How Law Is Suffocating AMERICA (1994). 
case in one of these skirmishes, it may prevent the Supreme Court from ever considering whether the D.C. Circuit's decision in SpeechNow is correct. Moreover, any ground that prevents the Supreme Court from considering the validity of SpeechNow is likely to block the Court from reviewing or reconsidering any other final decision striking down an election law, including Citizens United. Even people who applaud SpeechNow and Citizens United should be troubled by constitutional law's one-way ratchet and by decisions that permanently immunize lower court decisions and fiveto-four Supreme Court decisions from reconsideration. 331

\section{CONCLUSION}

A reader might well ask, "If the arguments presented in this paper are sound, why have twenty-four federal circuit judges in six federal courts of appeals rejected them?” The premise of the question, however, is mistaken. No judge has rejected any of the arguments presented in this paper.

Many judges have disagreed with this Article's ultimate conclusions (1) that federal limits on contributions to super PACs are valid and (2) that nothing in Citizens United should lead to a contrary conclusion. As the SpeechNow bandwagon gained momentum,332 however, no court focused on any of the arguments this Article has offered in support of its position. As

331. What position the Justice Department will take when Lieu v. FEC reaches the court of appeals and the Supreme Court is uncertain. In SpeechNow, the Justice Department defended the constitutionality of the federal statute limiting contributions to super PACs, and "[a] major part of the duty of the Solicitor General is to defend laws passed by Congress." Stephen Wermiel, SCOTUS for Law Students: What Does the Solicitor General Do?, SCOTUSBLOG (May 2, 2012, 10:44 AM), http://www.scotusblog.com/2012/05/scotus-for-law-studentswhat-does-the-solicitor-general-do-sponsored-by-bloomberg-law/ [https://perma.cc/BC3VXNYU]. Indeed, "[t]he Office generally takes the position that it will defend any act of Congress for which there is a plausible argument to be made that a statute is constitutional." Id. The Department's duty to defend a congressional enactment, the validity of which the Supreme Court has never considered, should trump its obligation to defend the position of a particular federal agency that has declined to enforce this enactment in reliance on a lower court decision. The Solicitor General should decline to represent the FEC and should allow this body to be represented by other counsel. He should in fact file an amicus brief in support of the plaintiffs' position.

President Trump's denunciations of super PACs and the administration's political interests also counsel support for the plaintiffs. Championing the right to give $\$ 20$ million to a super PAC would not make any administration popular, and, in view of President Trump's strong statements on the subject, it would be especially incongruous for his administration to defend this supposed right. See supra notes 237-43.

332. Compare N.Y. Progress \& Prot. PAC v. Walsh, 733 F.3d 483, 488 (2d Cir. 2013) ("Few contested legal questions are answered so consistently by so many courts and judges."), and Texans for Free Enter. v. Tex. Ethics Comm’n, 732 F.3d 535, 537 (5th Cir. 2013) ("We tread a well-worn path.”), with IRving L. JANIS, GroupthinK: PsychOLOGICAL STUDiES OF POLICY DECISIONS AND FiAsCOES (1982) (noting the tendency of groupthink to supplant independent critical thinking and describing how this phenomenon contributed to policy fiascoes in five presidential administrations). One naturally tends to assume that "Fifty Million Frenchmen Can’t Be Wrong,” see almonkitt, Sophie Tucker 50 Million Frenchmen Can't Be Wrong, YouTuBE (Dec. 29, 2007), https://www.youtube.com/watch?v=uIP0DE2kTI [https://perma.cc/W9YW-7D83], but they probably can be. 
best we can tell, these arguments simply were not advanced in any of the cases. 333

SpeechNow took as its premise one sentence of the Citizens United opinion: "[W]e now conclude that independent expenditures ... do not give rise to corruption or the appearance of corruption." 334 The D.C. Circuit declared that, if independent expenditures do not corrupt, the contributions that make these expenditures possible cannot corrupt either. 335

This Article offered two arguments about the Court's premise. First, this Supreme Court statement was dictum. It was in fact dictum twice over. 336 This statement came after the Court had resolved the case before it twice, and the statement advanced neither the Court's holding nor the "extra" ground of decision it suggested.

Second, the Supreme Court probably did not mean this statement literally.337 The D.C. Circuit's analysis depended on reading the statement to say not just that independent expenditures are insufficiently corrupting to justify their restriction but also that these expenditures do not corrupt even a smidgen. Other passages of Citizens United and the Court's decision in Caperton v. A.T. Massey Coal Co.338 suggest that the Court did not mean to sweep so far beyond the issues before it. Neither SpeechNow nor any of the decisions that followed it focused on whether this statement was holding rather than dictum, and none paused over indications that the Supreme Court might not have meant its statement literally.

We said that the SpeechNow syllogism itself was fallacious. Contributions to a super PAC can corrupt even when the group's expenditures do not corrupt and in fact do the world great good. As Buckley recognized, it is the people who write the checks - not the money spenders-who typically corrupt and create the appearance of corruption. 339 Neither SpeechNow nor any of the decisions that followed it examined challenges to the supposed syllogism.

We offered two criticisms of the syllogism's conclusion-that "contributions to groups that make only independent expenditures ... cannot corrupt or create the appearance of corruption." 340 First, this conclusion is silly. When a legislator agrees to vote in favor of widget subsidies in exchange for a $\$ 1$ million contribution to a super PAC supporting his candidacy, he commits the crime of bribery. Declaring that "there is no

333. Before Citizens United and SpeechNow, a Fourth Circuit panel concluded that North Carolina had not shown that contributions to independent expenditure committees were sufficiently corrupting to justify their limitation. N.C. Right to Life, Inc. v. Leake, 525 F.3d 274, 293-94 (4th Cir. 2008). Judge M. Blane Michael, however, dissented. Id. at 332-37 (Michael, J., dissenting). The vote in favor of striking down limits on contributions to super PACs thus has not been unanimous, and the late Judge Michael is our hero.

334. Citizens United v. FEC, 558 U.S. 310, 357 (2010).

335. SpeechNow.org v. FEC, 599 F.3d 686, 694 (D.C. Cir. 2010) (en banc).

336. See supra Part I.B.

337. See supra Part I.C.

338. 556 U.S. 868 (2009).

339. Buckey v. Valeo, 424 U.S. 1, 55-56 (1976) (per curiam).

340. SpeechNow, 599 F.3d at 694. 
corrupting 'quid' for which a candidate might in exchange offer a corrupt 'quo'”341 does not pass the laugh test. Yet the five courts of appeals that followed SpeechNow maintained straight faces, apparently because they did not notice that declaring super PAC contributions noncorrupting as a matter of law would make openly trading these contributions for government benefits a constitutional right.

Second, the syllogism's conclusion cannot be reconciled with Buckley $v$. Valeo, in which the Supreme Court said, "It is unnecessary to look beyond the Act's primary purpose to limit the actuality and appearance of corruption resulting from large individual financial contributions in order to find a constitutionally sufficient justification for the $\$ 1000 \ldots$. limitation [on contributions to candidates].”342 Neither the D.C. Circuit nor any of the courts that embraced its decision addressed what should have been the central issue in the cases before them-whether contributions to super PACs can reasonably be distinguished from the contributions to candidates whose limitation Buckley upheld.

Unlike SpeechNow or any of the decisions that echoed it, we reviewed the distinctions Buckley drew between contributions and expenditures. We noted initially that each of the three reasons Buckley offered for treating contributions to candidates as low-value speech applies fully to contributions to super PACs. Like a donation to a candidate, (1) a super PAC contribution does not convey the underlying basis for the contributor's support, (2) its transformation into debate requires speech by someone other than the contributor, and (3) limiting it does not prevent the contribution from serving as a symbolic expression of support or restrict the contributor's ability to discuss candidates and issues. To use the language of FEC v. Beaumont, Buckley and its progeny require treating contribution limits as "marginal speech restrictions subject to relatively complaisant review under the First Amendment, because contributions lie closer to the edges than to the core of political expression.”343

Moreover, one of the Buckley Court's two reasons for viewing contributions to candidates as less corrupting than expenditures applies equally to contributions to super PACs. Although the rules forbidding the coordination of independent expenditures with the expenditures of a candidate are thought to inhibit corrupt transactions between candidates and super PAC managers, they cannot inhibit corrupt transactions between candidates and super PAC donors. These rules do not limit what candidates and super PAC donors may say to one another.

The Buckley Court's remaining distinction between contributions to candidates and independent expenditures was that direct contributions may be more valuable to candidates. Similarly, candidates may value contributions to their official campaigns more than they do contributions to super PACs. A candidate, however, does not value a $\$ 5500$ contribution to

341. Id. at 694-95.

342. Buckley, 424 U.S. at 26.

343. FEC v. Beaumont, 539 U.S. 146, 161 (2003). 
his campaign more than he does a $\$ 1$ million contribution to a super PAC whose mission is to support his candidacy. The Supreme Court's ruling that Congress may prohibit the $\$ 5500$ contribution because it is corrupting or creates the appearance of corruption cannot be reconciled with the D.C. Circuit's ruling that the $\$ 1$ million contribution is protected because it does not create even an appearance of corruption. SpeechNow and the decisions echoing it have created a perverse campaign finance regime-one in which, although donations supporting candidates are unlimited, donors must channel these donations to less responsible, more destructive, and less authoritative speakers than the candidates themselves.

The ultimate question posed by Buckley is whether super PAC contributions create a sufficient appearance of corruption to justify their limitation. In 2018, the appearance of corruption in America is widespread and intense. In the presidential campaign of 2016, candidates of both parties decried government by the wealthy and denounced super PACs. Condemnations of "Wall Street," "Silicon Valley," "Hollywood," "the billionaire class," "big banks," "super PACs," and "the one percent” now seem as common as denunciations of ISIS. Opinion polls confirm the public's loss of faith in our democracy, and Washington insiders voice the same discouragement and mistrust as the public. The super PACs spawned by SpeechNow have become powerful symbols of corruption.

Because the most recent of the decisions endorsing SpeechNow came in 2013, the authors of these decisions could not have known the full extent of the appearance of corruption their decisions would produce. Moreover, the judges who decided SpeechNow in 2010 might have been unaware not only of the consequences of abrogating the limits on political contributions but also of the fact that they were abrogating these limits. David Keating, president of the nonprofit association SpeechNow and the principal architect of the SpeechNow litigation, told an interviewer in 2015 that using an independent expenditure group to promote a particular candidate "just never entered my mind. . . . But it's totally obvious when you think about it.”344 Attorney General Holder said that the Justice Department did not seek Supreme Court review of SpeechNow because this decision would "affect only a small subset of federally regulated contributions." 345 The judges of the D.C. Circuit might have been no less oblivious than the parties on both sides to the beast that was about to emerge from their opinion. 346

SpeechNow in fact transformed American politics, intensified class division and mistrust, and helped to reduce faith in our democracy to a nadir. A ruling so consequential should not have been left to the D.C. Circuit or

344. Alex Altman, Meet the Man Who Invented the Super PAC, TimE (May 13, 2015), http://time.com/3856427/super-pac-david-keating/ [https://perma.cc/J8YP-AEYP].

345. Letter from Eric H. Holder, Jr., supra note 36.

346. One of the FEC's briefs in SpeechNow noted, however, “[S]uccess for SpeechNow could lead to the proliferation of independent expenditure political committees devoted to supporting or opposing a single federal candidate or officeholder and funded entirely by very large contributions.” Brief for the Federal Election Commission at 45, SpeechNow.org v. FEC, 599 F.3d 686 (D.C. Cir. 2010) (No. 08-5223). The FEC filed this brief before the D.C. Circuit agreed to consider SpeechNow en banc; it was not the brief addressed to the court en banc. 
even to six courts of appeals. Eight years after SpeechNow, the ability of Congress to limit super PAC contributions awaits and requires the Supreme Court's attention.

Stay tuned. 347

347. After the authors and editors completed work on this Article, the U.S. District Court for the District of Columbia granted plaintiffs' motion to amend the complaint in Lieu v. FEC, a case discussed supra Part IV. Minute Order Granting Plaintiff's Motion for Leave to Amend Complaint and Denying Defendant's Motion to Dismiss for Lack of Jurisdiction as Moot, Lieu v. FEC, No. 16 Civ. 2201 (EGS) (D.D.C. Mar. 7, 2018). The FEC is now likely to present many of the same arguments on a motion to dismiss or a motion for summary judgment that it made in contending that amending the complaint would be futile. 